\title{
Ownership-Control Discrepancy and Firm Value: Evidence from France
}

\author{
Sabri Boubaker \\ Université Paris XII, Val de Marne, France
}

The purpose of this study is to provide an empirical analysis of the relationship between ownership structure of French firms and their value. Using data for 510 French publicly traded firms, the current study provides evidence in support of the entrenchment hypothesis. The results show that large controlling shareholders maintaining grip on control while holding only small fraction of cash flow rights are inclined to expropriate minority shareholders, which in turn detrimentally affects the firm's valuation. The evidence also indicates that pyramiding is the main device set to unduly entrench the large controlling shareholder. Additional analysis reveals that the identity of the second largest controlling shareholder matters. Sharing control with a family constrains the largest controlling shareholder to steer clear of self-serving behavior. However sharing control with a widely held firm or with a financial institution fosters this self-serving behavior (JEL: G32, G34).

Keywords: ownership structure, corporate governance, minority expropriation.

\section{Introduction}

The corporate finance literature has focused on mitigating the conflict between hired managers who are unaccountable to outsiders and dispersed shareholders due to the separation of ownership and control. Recent studies sharply contrast with Berle and Means' (1932) model of widely diffused corporate ownership and suggest that the presence of controlling shareholders is widespread throughout the world, even in

\footnotetext{
* The author acknowledges helpful comments from Ken Bechmann, Rüdiger Fahlenbrach, Jean-François Gajewski, Édith Ginglinger, Pascal Grandin, Richard Heaney, Florence Labégorre, Meziane Lasfer, Myron Slovin, Marie Sushka, Arnaud Thauvron, seminar participants at Université Paris I Panthéon -Sorbonne, CEREG-Université Paris IX Dauphine, Université Paris XII Val de Marne, Lille Graduate School of Management, and participants at the 2003 Multinational Finance Society meeting in Montreal, Canada, the 2003 French Finance Association meeting in Lyon, France, and the 2nd International Finance Conference in Hammamet March 2003 (Tunisia) and an anonymous referee of the journal for his insightful comments and suggestions. All errors are my own responsibility.
}

(Multinational Finance Journal, 2007, vol. 11, no. 3/4, pp. 211-252)

(C) by Multinational Finance Society, a nonprofit corporation. All rights reserved. DOI: $10.17578 / 11-3 / 4-3$ 
developed countries including the United States (see, e.g., Shleifer and Vishny [1997], Holderness, Kroszner, and Sheehan [1999], and La Porta, Lopez-de-Silanes and Shleifer [1999]). Indeed, Holderness, Kroszner, and Sheehan (1999) document a higher managerial ownership for U.S. listed firms nowadays than earlier in the century when the Berle and Means study was undertaken. ${ }^{1}$ La Porta, Lopez-de-Silanes, and Shleifer (1999) studied the ownership structure of large corporations in 27 wealthy countries and found that $64 \%(76 \%)$ of these corporations feature a controlling shareholder at a $20 \%$ cut-off point (10\% cut-off point). In a similar study on 9 East Asian countries, Claessens, Djankov, and Lang (2000) document that almost $68 \%$ of the firms are controlled by a single shareholder and that the separation of management from ownership control is rare.

In European countries, corporations exhibit a large controlling shareholder who owns control rights in excess of his/her cash flow rights and who hires and closely monitors corporate managers (Barca and Becht [2001]). Faccio and Lang (2002) carried out a study of the ownership and control for 5,232 corporations in 13 Western European countries and found that $63 \%$ of the firms have an ultimate controlling shareholder who often owns much more control rights than cash flow rights. Evidence, therefore, indicates that in continental Europe, the relevant issue has shifted from the traditional agency conflict between professional managers and atomistic shareholders to an equally salient agency conflict between controlling shareholders and minority shareholders. The need to focus on such a conflict has become more acute, all the more so that it was one of the causes of the 1997-98 East Asian financial crisis and its aftermath. ${ }^{2}$

The issue of the divergence between ownership and control, as one of the major causes of minority expropriation, has been shrugged off until recently. Since little has been done on the topic, our understanding is limited and general conclusions cannot be drawn. Our study is carried out on a sample of 510 French publicly traded firms. France is characterized by poor investors' protection rules, by an inefficient law enforcement system, and is deemed to provide a favorable context to minority expropriation (La Porta, Lopez-de-Silanes, and Shleifer [1999]). The French court seldom admits the liability of directors or controlling

1. Holderness and Sheehan (1988) report that numerous listed U.S. firms have majority shareholders, i.e., ownership greater than $51 \%$. U.S. listed firms remain less concentrated than those in Europe because of legal constraints on ownership (Holderness and Sheehan [1998]).

2. See for extensive details Johnson et al. (2000 a and b) and Mitton (2002). 
shareholders to indemnify the harm caused to minority shareholders. Moreover, a long law suit period is often required to cancel or to modify an unfair resolution taken by the insiders (Gérard [2001]). ${ }^{3} \mathrm{We}$ investigate the valuation effects of the ownership and control structures effectively adopted. In fact, despite the weak legal and the institutional environment, corporations might commit themselves not to expropriate minority shareholders by privileging some ownership and control patterns, thus having less value discount than are other firms.

The objective of the paper is to test the impact of the presence of large controlling shareholders and of ownership-control discrepancy on firm value for French listed firms. The present study provides evidence in support of the entrenchment hypothesis. Large controlling shareholders maintaining grip on control while holding only a small fraction of cash flow rights are inclined to expropriate minority shareholders, which in turn detrimentally affects the firm value. The evidence also indicates that pyramiding is the main device set to unduly entrench the large controlling shareholder. Additional analysis reveals that the second largest shareholder plays a monitoring role if he or she happens to be member of the controlling family.

The remainder of the paper is structured as follows: section II presents hypotheses with respect to the presence of the large controlling shareholder, the discrepancy between ownership and control, and the mechanisms used to maintain control. The same section presents the pros and the cons of the involvement of the large controlling shareholder in the management and discusses the outcome of a multiple controlling shareholders' situation. Data selection, variables construction and methodology are described in section III. The descriptive statistics and multivariate results are portrayed in the penultimate section. Section V concludes the paper.

\section{Hypotheses Development}

In the present section of the paper, we discuss the possible outcome of the situation where a large controlling shareholder maintains control through a small fraction of the cash flow rights. We examine whether the identity of the large controlling shareholder matters and we discuss the implications of his/her involvement in the management. We also examine

3. See the French law no. 89-532 (August 1989) and the French law no. 94-679 (August 1994) for details on minority shareholders' rights in France. 
the theoretical arguments with respect to the possible beneficial and harmful effects of the presence of multiple controlling shareholders.

\section{A. The Presence of Large Controlling Shareholders}

Despite the substantial literature concerning the effect of large controlling shareholders or control concentration on firm value, there are no clear-cut findings yet. The presence of controlling shareholders with larger claims on the firm's cash flow rights might alleviate the free-riding problem in monitoring the management. It mitigates agency costs by aligning the controlling shareholders interests with those of the outsiders, (Shleifer and Vishny [1986]). Such shareholders are more prone to incur the monitoring costs-e.g., collecting and processing information-and to reap benefits commensurately with their ownership. The reduction of managerial discretion by monitoring is not exclusively beneficial. Its value-enhancing effect may be offset by the loss of managerial incentives (Burkart, Gromb, and Panunzi [1997]).

Several costs may be associated with the presence of large controlling shareholders. Bolton and von Thadden (1998) argue that the main drawback of maintaining a controlling block is that it lowers the stock's liquidity, thus increasing the firm cost of capital by foregoing the liquidity premium. This liquidity reduction might also cut back the informational content of stock prices (Holmstrom and Tirole [1993]) and aggravate the free-rider problem without eliminating the large shareholder's rents (Maug [1998]). Stulz (1988) argues that greater managers' holdings consolidate the power of the internal constituency vis-à-vis of the external constituency in influencing the firm's performance. Agency costs arise when the interests of the firm's managers are not in line with those of the firm's owners, and take the form of preference for on-the-job perks, shirking, and making self-serving decisions that reduce shareholder's wealth.

Overall, previous studies suggest that both costs and benefits are associated with large controlling shareholders. The actual effect on the firm value is the result of weighing the pros and the cons of such presence. This constitutes an empirical issue.

\section{B. Ownership-control Discrepancy: Effects and Devices}

Bebchuk (1999) shows that the presence of large controlling shareholders is inclined to exist along with a separation of cash flow rights and voting 
rights. Such separation has the potential to create sizeable agency costs and may be a backlash against minority protection, especially when there is an overlapping of ownership and management. This structure is prevailing in many East Asian countries (Claessens, Djankov, and Lang [2000]) and in continental European countries (Faccio and Lang [2002]) where families usually own several firms through complex ownership structures. France is typical in this respect.

\section{Beneficial and Harmful Effects of Ownership-control Discrepancy}

La Porta, Lopez-de-Silanes, and Shleifer (1998) provide evidence that countries whose legal rules originate in civil-law tradition, as France, have a low quality of law enforcement and tend to poorly protect minority shareholders. In such countries, the divergence between control rights and cash flow rights is a rule rather than an exception and it is easier and less costly for the entrepreneur to set up ownership structures facilitating fund diversion. Wolfenzon (1999) among others suggest that controlling shareholders resort to complex and often inefficient schemes so as to dodge minority protection legal rights, to circumvent various enforcement devices or to deceive outside shareholders. ${ }^{4}$ Grossman and Hart (1988) demonstrate that the deviation from the one-share-one-vote rule maximizes the benefit of control to the controlling party relative to security holders and thus might not be socially optimal. Morck, Shleifer, and Vishny (1988) explain the negative relation between ownership and firm value-in the $5 \%-25 \%$ ownership range - as an entrenchment effect due to the quasi-entire control of the firm with only a small fraction of cash flow rights. Within this range, controlling shareholders are willing to extract private benefits at minority's expense. Bebchuk (1999) and Bebchuk, Kraakman, and Triantis (2000) contend that some ownership patterns -e.g., pyramiding, cross-holdings and dual class shares-might exacerbate the extent of private rents by favoring some forms of controlling shareholder's misbehavior. These potentially large agency costs caused by the severe wedge between ownership and control are only partly internalized by the controlling shareholder proportionally to his/her cash flow claims while he/she captures the most part of the

4. Bianchi, Bianco and Enriques (2001) argue that pyramid is used also as an elusive device to hide the identity of the ultimate owner of the firm, to limit its liability and to eschew some disclosure constraints. 
diverted funds. ${ }^{5}$ Bebchuk, Kraakman, and Triantis (2000) demonstrate that, holding controlling stake constant, the agency costs' size is shown to rise nonlinearly in a sharply increasing rate when the fraction of cash flow claims held by the largest controlling shareholder decreases. Theses arguments lead to the following hypothesis:

Hypothesis I: The higher the firm's ownership-control discrepancy the lower the firm value.

\section{Control Devices}

The devices enabling a shareholder to control a firm while retaining only a small fraction of the cash flow claims are chiefly stock pyramids, dual-class share structures, and cross-holdings. Bebchuk, Kraakman, and Triantis (2000) demonstrate that for any desired ownership-control discrepancy level, whatever its extent, one of the above devices may allow a shareholder to make a locus of control without owning more than a predefined fraction of cash flow rights. This discrepancy level may be achieved also by combining two or more mechanisms.

Among these mechanisms, pyramiding is the most frequently used device to maintain grip on control while owning only a tiny proportion of the equity claims (La Porta, Lopez-de-Silanes, and Shleifer [1999]). Pyramiding allows the overarching family or the parent company to control a wide range of affiliated firms via several layers of intermediary companies and to interfere in their management. This hazy pattern shackles outside monitoring and ensures to the ultimate owner the imperviousness of minority scrutiny so as to enjoy and to warrant private benefits of control. Pyramiding is a propitious pattern to the emergence of other forms of expropriation-called tunnelinginasmuch as it makes it easier channeling the company's resources from lower-layers located firms towards upper-layers located firms. In the latter the insider's ownership is often more concentrated. The

5. Let's consider a simple pyramiding case where a wholly-owned family firm A holds $40 \%$ of the direct cash flow rights and $51 \%$ of the direct voting rights $(C=40 \%, V=51 \%)$ of a firm B. Firm B itself controls $(C=30 \%, V=40 \%)$ of firm C which in turn holds $50 \%$ in firm $\mathrm{D}$ (Firm D has a one-share-one-vote structure). The family is considered as the ultimate controlling shareholder of firm $\mathrm{D}$. The control is maintained through pyramiding. The family owns $6 \%(40 \% \times 30 \% \times 50 \%)$ of the cash-flow rights $(U C F 1)$ of firm D measured as the product of its ownership interests along the control chain and its control rights (UCO1) equal to $40 \%$ computed as the weakest link in the control chain $(\min (51 \%, 40 \%, 50 \%))$. If firm A sells goods or services to firm $\mathrm{D}$ at over the market prices by $\$ 1000$, then the minority shareholders' loss gained by the family is $1000 \times(1-6 \%)=\$ 940$ (figure 1$)$. See figure 2 , for an actual example. 


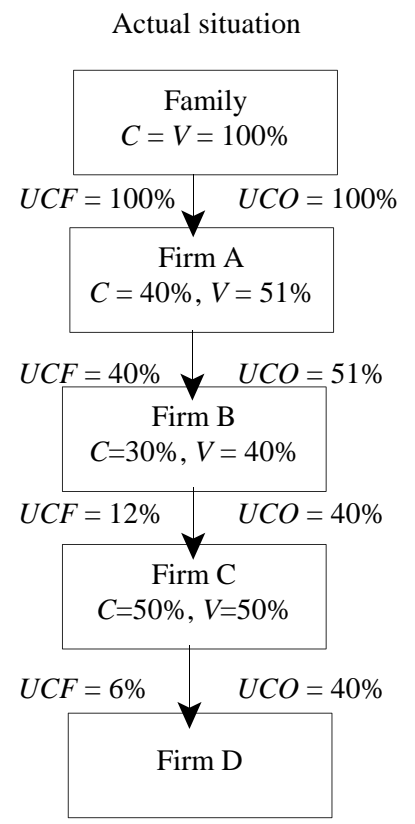

One-share-one-vote situation

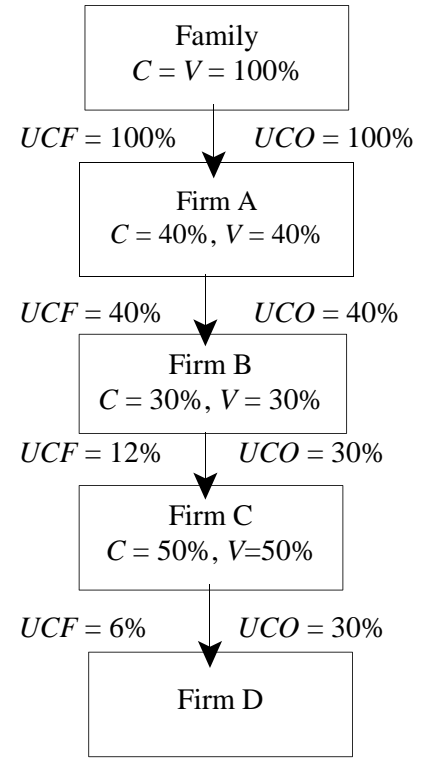

FiguRE 1.-An Example of Pyramiding

This figure illustrates a simple pyramiding case. " $C$ " and " $V$ " denote respectively direct cash flow stakes and direct voting stakes of the direct controlling shareholder. They are reported in the firms' boxes. The ultimate cash flow stakes $(U C F)$ and the ultimate control stakes $(U C O)$ are shown below the firm's boxes. The family owns $6 \%(40 \% \times 30 \% \times 50 \%)$ of the cash-flow rights of firm D measured as the product of its ownership interests along the control chain and its control rights equal to $40 \%$ computed as the weakest link in the control chain (min $(51 \%$, $40 \%, 50 \%)$ ). The overall ownership-control discrepancy is measured by control minus ownership over control $((\mathrm{UCO}-U C F) / U C O)$ and equals $((40 \%-6 \%) / 40 \%)=85 \%$. To disentangle between ownership-control discrepancy due to pyramiding and that due to non-traded high voting shares, we suppose an hypothetical situation of one-share-one-vote rule (i.e., the only mechanism used to enhance control is pyramiding). The ultimate cash flow rights (UCFpyr), the ultimate control rights (UCOpyr), and the Excess control (Excess control pyr) due to pyramiding are computed. The difference between the overall Excess control and the Excess control due to pyramiding is that due to the non-traded high voting shares. Here the overall excess of control equals $((U C O-U C F) / U C O)=(40 \%-6 \%) / 40 \%=85 \%$ (actual situation $)$ and the excess due to pyramiding equals ( (UCOpyr - UCFpyr $) / U C O p y r)=(30 \%$ $-6 \%$ ) $/ 30 \%=80 \%$ (one-share-one-vote situation). Hence, the Excess control due to non-traded high voting shares (Excess control $h v$ ) equals $(85 \%-80 \%)=5 \%$.

lower-layers located firms may often experience disadvantageous contract terms for selling (buying) corporate assets, goods or services at below (above) market prices within the pyramid. The controlling shareholder may also give sweet deals to closely owned firms or set 


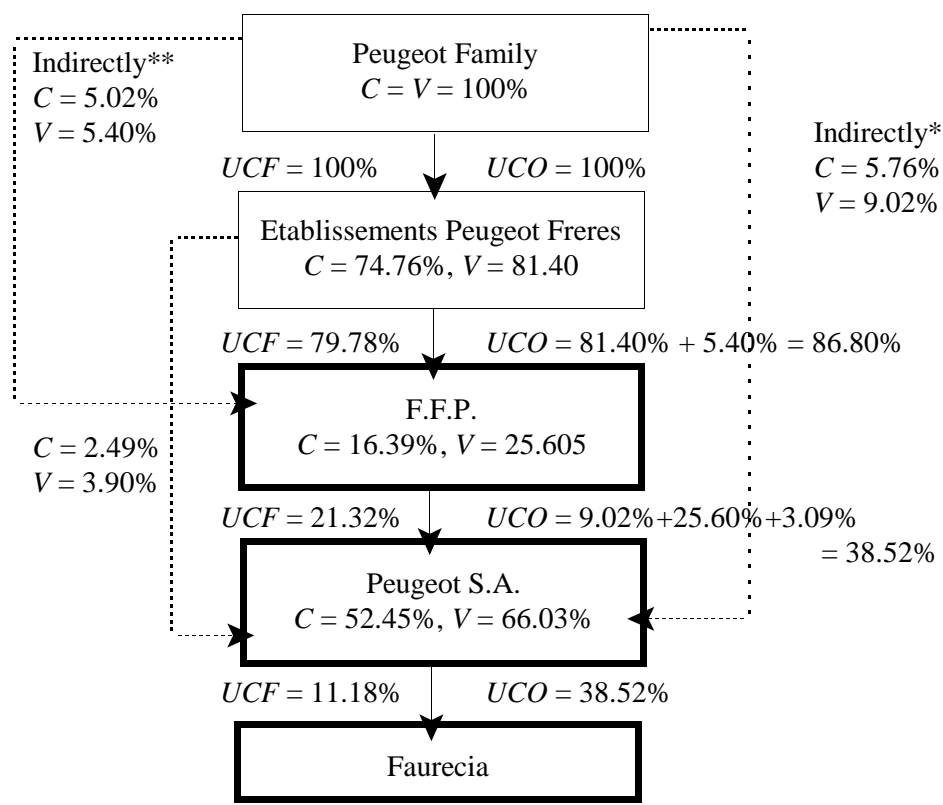

* Indirect control mainly through (La Française de Participations Financières [ $\mathrm{C}=$ $3.52 \%, V=5.52 \%]$ and Cogevam $[C=2.23 \%, V=3.49 \%])$

** Indirect control through three unlisted firm (Immeubluess et Participations de l'Est $[C=0.92 \%, V=1.00 \%]$, S.A. Comtoise de Participation $[C=2.07 \%, V=$ $2.30 \%]$ and La Française de Participations Financières $[C=1.97 \%, V=2.10 \%]$ ).

\section{FIGURE 2.-The Peugeot Group}

This figure elucidates how Faurecia is controlled by Peugeot Family. Hard lines and dotted lines indicate respectively pyramiding and holding through multiple control chains. Firms in thick boxes are publicly traded firms. All listed firms have non-traded high voting shares but do not have any non-voting shares. The control of Faurecia is exercised through a combination of pyramiding, holding through multiple control chains and non-traded high voting shares. Peugeot S.A. directly controls Faurecia with a direct stake of $(C=52.45 \% ; V=66.03 \%)$ and is itself controlled by four principal shareholders within the group: 1 / Three unlisted wholly controlled firms by Peugeot family (Etablissements Peugeot Frères $(C=2.49 \% ; V=3.90 \%)$, La Française de Participations Financières $(C=3.52 \% ; V=5.52 \%)^{*}$, and Cogevam $(C=2.23 \% ; V=$ $3.49 \%)^{*}$ ), and 2 / La société Foncière, Financière et de Participation (F.F.P) a financial listed firm with a direct stake of $(C=16.39 \%$; $V=25.60 \%)$ which in turn is controlled by Peugeot family indirectly through Etablissement Peugeot Frères $(C=74.76 \% ; V=81.40 \%)$, Immeubles et Participations de l'Est $(C=0.92 \% ; V=1.00 \%)^{* *}$, S.A. Comtoise de Participation $(C=$ $2.07 \% ; V=2.30 \%)^{* *}$, and La Française de Participations Financières $(C=1.97 \% ; V=$ $2.10 \%)^{* *}$. The ultimate cash flow stake is computed as the sum of the products of ownership stakes along the different control chains. Thus Peugeot family's overall ultimate cash flow stake $(U C F)$ in Faurecia is $52.45 \% \times 16.39 \% \times 5.02 \%+52.45 \% \times 2.49 \%+52.45 \% \times 16.39 \% \times$ $74.76 \%+52.45 \% \times 5.76 \%=11.18 \%$. The ultimate control stake $(U C O)$ is computed as the weakest control in the pyramid chain, which gives $(\min (66.03 \%, 9.02 \%+25.60 \%+3.90 \%$, 
$81.40 \%+5.40 \%, 100 \%)=38.52 \%$ ). With $38.52 \%$ of control rights, Peugeot Family is the sole controlling shareholder of Faurecia at $10 \%$ threshold. The overall ownership-control discrepancy is measured by ultimate control minus ultimate ownership over ultimate control ((UCO - UCF) / UCO) and equals $70.98 \%$ for Faurecia. Using the methodology described in figure 1, the ownership-control discrepancy due to pyramiding and that due to non-traded high voting shares are disentangled. The ultimate cash flow rights due to pyramiding (UCFpyr) equal to $11.18 \%$. The ultimate control rights due to pyramiding (UCOpyr) equal to min $(52.45 \%, 2.49 \%+$ $16.39 \%+5.76 \%, 74.76 \%+5.02 \%, 100 \%)=24.64 \%$. The excess control due to pyramiding (Excess control pyr) equals $((U C O p y r-U C F p y r) / U C O p y r)=(24.64 \%-11.18 \%) / 24.64 \%$ $=54.63 \%$. Since overall Excess of control equals $70.98 \%$ then the excess control due to non-traded high voting shares (Excess control $h v$ ) equals $(70.98 \%-54.63 \%)=16.35 \%$.

unfair terms for loans, transfers, trade credits and so on (see, e.g., Johnson et al. [2000b]).

Another mechanism is cross-holding. Being horizontally interconnected, cross-holdings provide insulation and entrenchment to controlling shareholders. The needed voting rights to maintain a lock on control over an array of firms are, unlike pyramids, distributed among the whole array instead of being the property of a single family or a parent company. This device is uncommon in France despite the plenty of leeway that the law gives to use this kind of arrangement (Faccio and Lang [2002]). ${ }^{6}$ The use of dual-class shares is generally subject to some restrictions. In many countries, corporate law caps the proportion of low-vote shares and/or restricts the voting ratio between high-vote and low-vote shares (Bebchuk, Kraakman, and Triantis [2000]). ${ }^{7}$ French firms are allowed to grant a second vote to faithful shareholders when they hold a registered stock for, at least, a two-year period. These high-voting shares, omitted in previous studies, are not publicly traded on the French Stock Exchange, and are hence closely held. French firms are accustomed to use voting pacts or in-concert actions with preemption right clause to lock out other shareholders from control. Unlike pyramiding and non-traded high voting shares, cross-holdings and non-voting shares are uncommonly used in the French context as

6. The French commercial law prohibits some forms of cross-holdings but not others. In fact, a firm A cannot hold directly or through another firm B more than $10 \%$ of its own shares (Law no. 66-537. July 24, 1966, Art. 358-1). However, the same law authorizes a firm A to be controlled through cross-holdings if this firm holds a stake in firm B and B holds a stake in firm A indirectly through one or more other firms. Only one firm in the present study is concerned with such a situation.

7. Non-voting capital of French firms must not transcend $25 \%$ of the stock capital. Few French firms use non-voting shares (Muss [1998]). The following firms in our sample use this type of shares (Bouygues, Casino Guichard Perrachon, Eridania Beghin-Say, Essilor International, Legrand, L'Oreal, Pechiney, Sagem, Société du Louvre, Taittinger and Total Fina Elf). 
alternative devices to separate ownership and control. They will consequently be disregarded in the current study.

Finance scholars emphasize the primordial role of minority protection in the development of financial markets and instance several practices of unfair minority expropriation that might flourish especially when there is a divergence between ownership and control. (see, e.g., La Porta et al. [2000]). In fact, a controlling shareholder may take advantage of his/her position to overstaff or to hire unqualified family members with excessive compensations in key managerial positions. $\mathrm{He} / \mathrm{she}$ may also squander firm's funds on value destroying pet projects, consume perks or even, simply, abscond with firm's assets as through self dealing transactions. Moreover, expropriation may take the form of scheduling dividend payments in accordance with the controlling shareholder's consumption and investment programs, the form of diverting corporate opportunities to closely owned firms, or in other instances the form of investing in high private benefits projects despite their negative net present value. In sum, the corporate decisions might be taken in such a fashion as to be in harmony with the controlling shareholder's idiosyncratic utility. From the earlier-mentioned arguments, the following hypothesis might be drawn:

Hypothesis II: Firms where ownership-control discrepancy is maintained through pyramiding and/or non-traded high voting shares should be associated with lower value.

Hypothesis III: The firm's value should be lower in firms exhibiting a lock on control through voting pacts or in-concert actions.

\section{Identity of the Large Controlling Shareholder}

It is "common wisdom" among scholars and practitioners in the field of corporate governance that the ownership type matters in explaining firm valuation differences. Family shareholders try to preserve their reputation for a possible external funding (La Porta et al. [2000]). This reputation may act as a substitute for weak legal protection and poor enforcement of minority rules (which is often the case in the French civil law countries) (Gomes [2000]). DeAngelos and DeAngelos (1985) argue that family controlled firms-characterized by a long run relationship between its members and the firm-have less agency costs due to good monitoring. Further impetus to the monitoring process may come from the family own wealth being closely bonded to the firm's 
welfare. Moreover, controlling families often purvey a better oversight quality because of their expertise, tenure, longer horizon (Anderson and Reeb [2003]), and excellent information on the firm activities (Smith and Amoako-Adu [1999]). ${ }^{8}$

Notwithstanding the preceding arguments insinuating that family-controlled companies present many comparative advantages, family control may lead to severe inefficiencies. For instance, La Porta, Lopez-de-Silanes, and Shleifer (1999) argue that families are famed for favoring their own interests by implementing self-serving policies at the expense of outside residual claimants. DeAngelos and DeAngelos (2000) contend that families ensure themselves the loyalty of the management even in the case of no blood or no marriage ties. They instance the case of Time Mirror Company where the family desire for special dividends freezes some expansion plans and harms the firm performance.

Companies controlled by widely held firms or widely held financial institutions may display lesser agency costs than those controlled by families inasmuch as they are managed by professionals continuously subject to a dismissal threat and to a risk of a hostile takeover. On the other hand, some costs may rise when banks are simultaneously controlling shareholders and creditors. These financial institutions are ambivalent about whether to maximize firm value or fees (Boehmer [2000]). Widely held parent firms have the possibility through various deals to tunnel profits away from the subsidiary (Bertrand, Mehta, and Mullainathan [2002]).

State-controlled firms operate essentially in markets with significant externalities where they may favor social and political goals over profit maximization. These firms are generally privatized to be invigorated and thus may serve as "cash cows" for other activities. The staff of such firms is chosen on the basis of political connections rather than on their competence. Megginson, Nash, and Van Randenborgh (1994), among others, provide evidence that state-controlled firms exhibit higher performance levels than privately owned firms.

\section{Large Controlling Shareholder's Involvement in the Management}

Faccio and Lang (2002) document in a cross-country study of 13 Western European countries that in more than two-thirds of the family

8. James (1999) develops a model in which the intention to pass on the company to descendents impel family-owned firms to adopt an efficient investment policy. The long horizon of families reduces managerial myopia but it may induce non-value maximizing decisions such as forgoing liquidation to save firm viability. 
controlled firms, the controlling owner is a member of the top management team. Fama and Jensen (1983) argue that the existence of family ties between controlling shareholders and managers should lower the agency costs. The rationale behind their contention is that such owner-manager families are, at the same time, principals and agents. Many empirical studies have brought support to this contention. Daily and Dollinger (1992) evidence that family owned and managed firms display higher performance due to the unification of ownership and control. Daily and Thompson (1994) have found that family-managed firms behave no differently than other professionally managed firms with respect to strategic posture. Anderson and Reeb (2003) show using Standard \& Poor's 500 companies that family firms do outperform other non-family firms. Their result is shown to stem mainly from firms in which members of the controlling family belong to the senior management team. Anderson, Mansi, and Reeb (2003) argue that the desire of family managers to preserve their reputation gives them incentive to enhance the firm performance.

The involvement of the controlling shareholder in the firm management, however, may not necessarily be favorable to minority shareholders. The large leeway of the owner-manager over the company decisions may lead to the subordination of the firm objectives to those of the family and hence may hamper the firm performance. In a study of Thai firms, Wiwattanakantang (2001) shows that firms in which the controlling shareholders are involved in management exhibit poor accounting performance. Likewise, Maury and Pajuste (2005) have found that a family member in a CEO position has a negative effect on the firm value.

The above arguments suggest that the large controlling shareholders' involvement in the management generates both costs and benefits. It is thus left as an empirical task to detect the actual sign of its influence on the firm value.

\section{E. Multiple Controlling Shareholders}

Shared control constitutes a potential challenge to the incumbent large controlling shareholder who may be constrained by other shareholders not to stray from value maximization. In fact, other firm controllers may exercise their power by refusing to assent harmful business decisions and even by invalidating those taken through bringing derivative suits. Bloch and Hege (2002) argue that control benefits are less important on average when several blockholders are present. In fact, for the purpose of seizing control, the two leading blockholder vie with each other to 
garner minority votes by committing themselves to cut down rent extraction. The pivotal votes of minority shareholders in control contests force the second largest blockholder pledging to pursue a more pronounced value-enhancing strategy. Moreover, their model suggests that a decrease in the difference in block size between the leading shareholders heighten control contestability and reduces on average the breadth of control benefits. In the Gomes and Novaes (2001) model, the requisite unanimity agreement among all the controlling group members on various firm decisions implies a weak likelihood of rent extraction and entails less expropriation. This bargaining effect in favor of minority shareholders is counterweighed by the internal disagreements, which constitutes a hindrance to adopt all worthy projects. The resolution of this trade-off shows that the net effect of multiple controlling shareholders is contingent on firm characteristics. ${ }^{9}$

Conversely, the presence of multiple large shareholders might not suffice to reduce acting at minority shareholders expense. Zwiebel (1995) assumes in his general equilibrium model that control benefits are apportioned depending upon the relative extent of investors' interests. He suggests that a situation where several blockholders-each of them with insufficient stake to be unchallenged by other investorsis likely to occur. These moderate sized blockholders-under the assumption of divisible control benefits-are prone to take part in controlling coalitions in a manner allowing them to maximize their benefits from partial control. Hence, the impact of such setting on minority shareholders wealth is conditional upon the outcome of the trade-off between large controlling shareholder monitoring and being member of a coalition.

Empirically, results on the effect of multiple controlling shareholders on firm value are mixed. In their study of the ownership structure effects on dividend policy, Faccio, Lang, and Young (2001) find evidence that the multiple controlling shareholders collude in expropriating minority shareholders in Eastern Asia, but appear to help containing such expropriation in Western Europe. Maury and Pajuste (2005) focus on the interplay between the three largest shareholders using a sample of Finnish listed companies. They provide evidence that a strong third blockholder contributes in lessening expropriation especially in a high control contestability situation where the two other

9. Similarly, Bennedsen and Wolfenzon (2000) argue that when investor protection is weak, diluting control among numerous controlling shareholders can serve as a commitment device to dampen minority expropriation. Pagano and Roell (1998) argue that multiple blocks may engage the firm in protecting minority investors. 
major shareholders hold relatively similar voting stakes.

Nevertheless, these two shareholders tend to collude when they jointly hold a majority. In a study of the German listed firms, Lehmann and Wigand (2000) show a positive incidence of the presence of an important second or third large shareholder on firm profitability. ${ }^{10}$ The above-arguments on the presence of multiple controlling shareholders lead to the following hypothesis:

Hypothesis IV: Sharing control should influence positively the firm value.

\section{Data Construction and Methodology}

\section{A. Data Sources}

This study is based on a unique manually gathered database on the ownership and voting structure of publicly traded corporations in the French Stock Market. Ownership and voting data were mainly retrieved from firms' annual reports, which are obtained either in hard copy form or in an electronic form from the COB's (Commission des Operations de Bourse) database. Firm's websites, direct contact with investors' relation services and the Registre de Commerce were used to supplement the data with information on firm's affiliates and their stakes. Annual reports - the main ownership data source for this study - provide information on shareholders with at least, $5 \%$ of the cash-flow stakes. Numerous firms disclose more detailed data even with $0.5 \%$ of ownership or voting rights. These firms often provide such details when there is a bylaw threshold notification clause of ownership or when a shareholder owning a small fraction (less than 5\%) is a member of a group of shareholders forming a voting syndicate. ${ }^{11}$

10. Boehmer (2000) examines acquisitions by German listed firms and finds that bank's ownership is harmful if its presence as the largest shareholder is without counterbalancing shareholding. Also, a beneficial effect is detected when the bank is complementing a family or a corporation as the second or third largest stakeholder. Ginglinger and L'Her (2006) look at stock price reaction to the open market stock buyback announcements in the France. Their results suggest a positive price reaction for firms having a second major shareholder of different identity than the largest one.

11. The French law no. 89-531 of August 2, 1989 constrains any individual or legal entity acting by himself or in-concert, who crosses upward or downward, directly or indirectly the $1 / 20,1 / 10,1 / 5,1 / 3,1 / 2$ or $2 / 3$ threshold of any firm listed on the French Stock Market with its headquarter in France to inform the competent authorities within a fifteen days period. Beside the compulsory disclosure rule, several firms adopt statutory thresholds in their bylaws. 
Data used in this study is end-of-year data for 2000 or end of the fiscal 2000. For some firms, data was collected at different points of time during 2000. Examining threshold-crossing notifications published by the CMF (Conseil du Marché Financier) and verifying the stability of the ownership and voting structure over the 1998 - 2000 period allows us to check the appropriateness of such figures for those firms. Any firm traded on the French Stock Market with its head office on French territory is included in the sample when it meets the four following criteria. First, the primary industry must not be financial, i.e., not one-digit-SIC (Standard Industrial Classification) code of 6 due to their operational and financial specificities. Second, all accounting data used in the analysis must be reported in the Worldscope database. Third, we must have complete ownership and voting information and could trace back the ultimate owner by following the ownership chain. Finally, the firm has to be listed prior to 2000. Taking into consideration these restrictions, we are left with a sample of 510 companies. The 2000 year-end market capitalization of the 510 companies in the sample amounts to about $91 \%$ of the year-end market capitalization of all non-financial companies listed in the French Stock Exchange.

\section{B. Ownership and Control Variables Construction}

The database used in the current study overcomes some data shortcomings of previous relevant studies on the French context. It provides a more comprehensive description of the ownership and voting structure and of the various devices employed to warrant the excess of control over ownership. ${ }^{12}$ The ownership and voting figures collected from the various sources mentioned take into account not only the effect of non-voting shares but also non-traded high voting shares. These figures are corrected by taking into consideration the presence of voting caps when used. In consistency with La Porta, Lopez-de-Silanes, and Shleifer (1999), we meticulously trace the ownership of any firm back to the ultimate owner. Generally, the direct owner of a firm is a financial corporation, a listed or an unlisted firm. We identify the direct owners, the owners of those owners, etc. We stop going back up when we encounter no shareholder in a given layer of the chain with at least $10 \%$ control stake or an individual shareholder. Individual owners linked by blood or marriage ties are considered as a unit of analysis

12. Bloch and Kremp (2001) studied the French top 40 firms ranked by market capitalization. Their data do not represent as argued by Faccio and Lang (2002) neither ultimate ownership nor ultimate control stakes. 


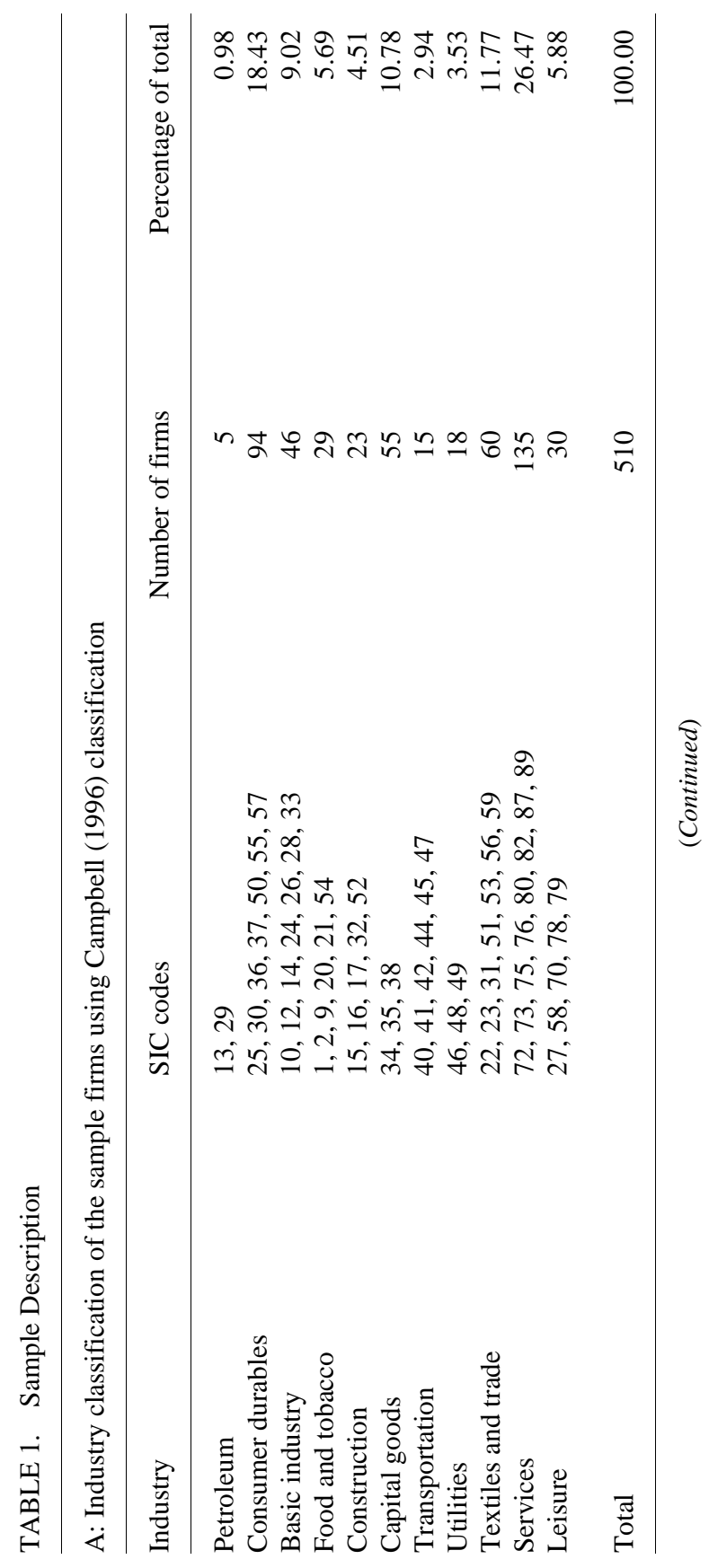




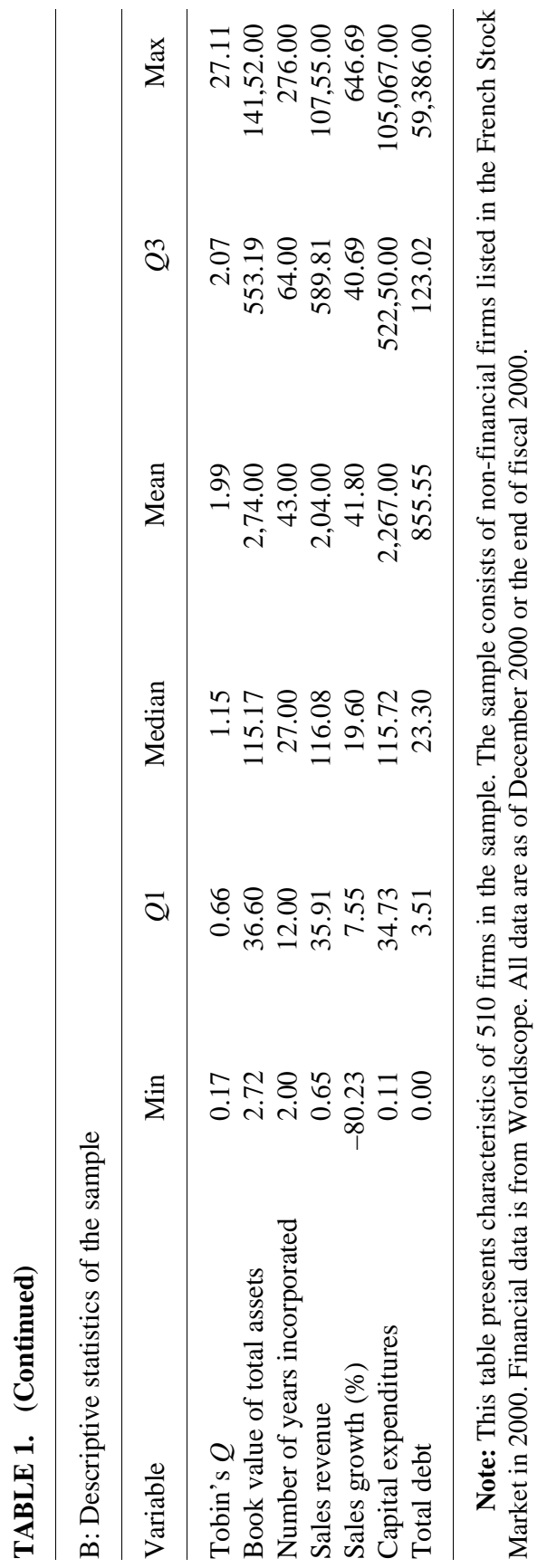


since they are likely to act together. The ownership and control right of different family members was aggregated notwithstanding the possibility of sib quarrels concerning control. For many firms, we were able to track down the relationship between controlling shareholders and the management, beyond their surnames.

In line with earlier studies, a $10 \%$ cut-off level is employed throughout the paper to track down the ultimate owner. We use the $20 \%$ cut-off point just to describe ownership and control characteristics of the firms. We document the nature of the ultimate controlling shareholder, the means used to maintain lock on control and we measure the extent ownership-control discrepancy. A firm is qualified as widely held at a specified threshold if none of its shareholders holds voting stakes exceeding that threshold. We apply the commonly used classification of the ultimate owners into five types: a family, a widely held firm, a widely held financial institution (SIC 6000-6999), the state, or a miscellaneous owner (i.e., a charity, a voting trust, a cooperative, employees...).

\section{Results and Analysis}

\section{A. Descriptive Statistics}

Table 1 (panel A) displays some descriptive statistics for companies in the sample and shows their distribution across industries using Campbell's (1996) grouping. The main three industries represented in the firms' sample are services (26.47\%), consumer durables (18.43\%) and textile and trade $(11.77 \%)$. The representation of petroleum industry is next to nonexistent with less than $1 \%$ of the sample firms. Panel B reports summary statistics for Tobin's $Q$ and some other firm characteristics for the 510 companies in the sample. We use a simple version of Tobin's $Q$ ratio measured as the ratio of market value of equity plus book value of total debt over book value of total assets. The median value of Tobin's $Q$ equals 1.15 suggesting that less than half of the sample's firms destroy value. The firms in the sample vary from recently incorporated companies (Bricodeal, Digigram...) to centennial firms (Bollore, Peugeot...) and from small firms like Alpha Mos and Aures Technologies to huge multinationals such as Vivendi Universal or Suez.

Table 2 shows the identity of the controlling shareholders at $10 \%$ (panel A) and 20\% (panel B) cut-off point, their ultimate cash flow and control rights, and the means they used to enhance control (panel C). Not surprisingly, only $5.50 \%$ (15.10\%) of the French listed firms are 


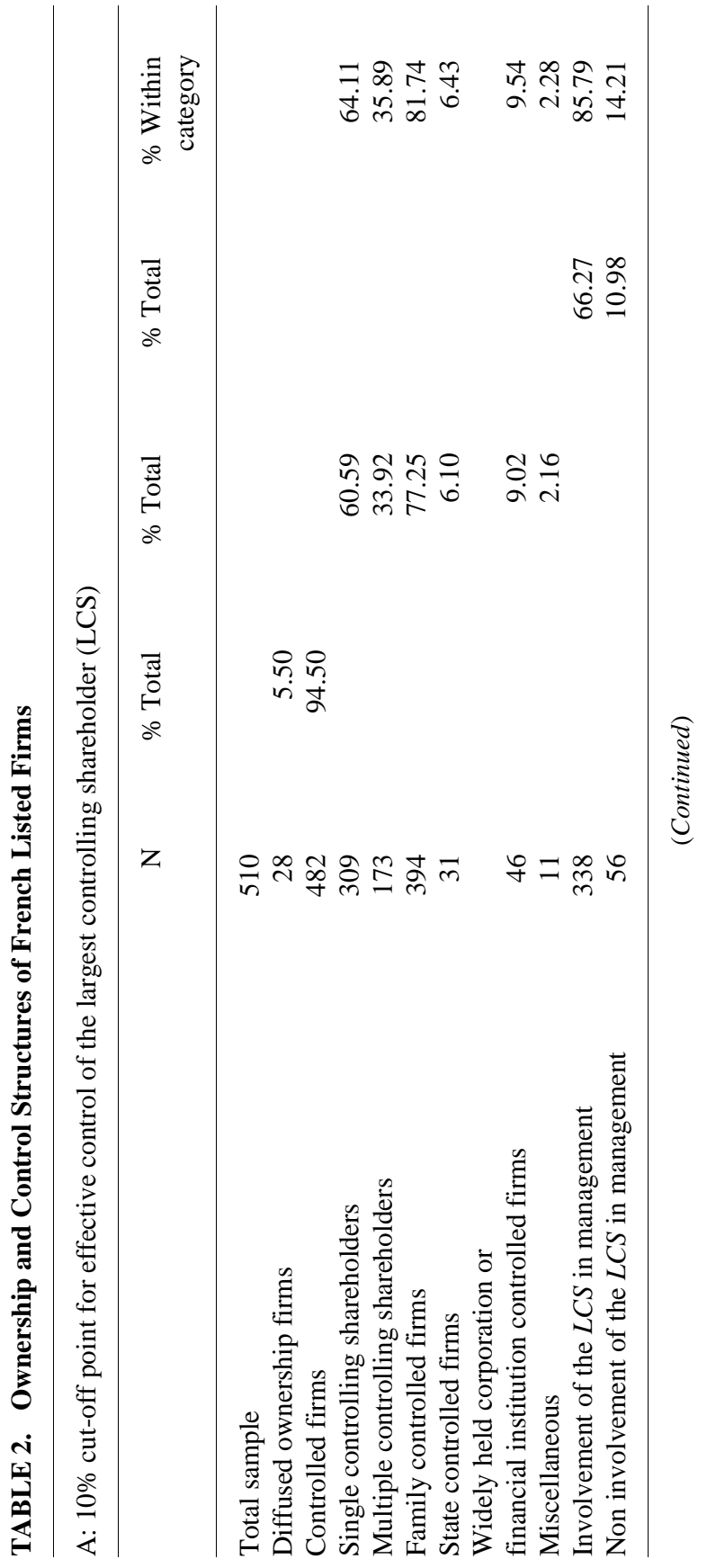




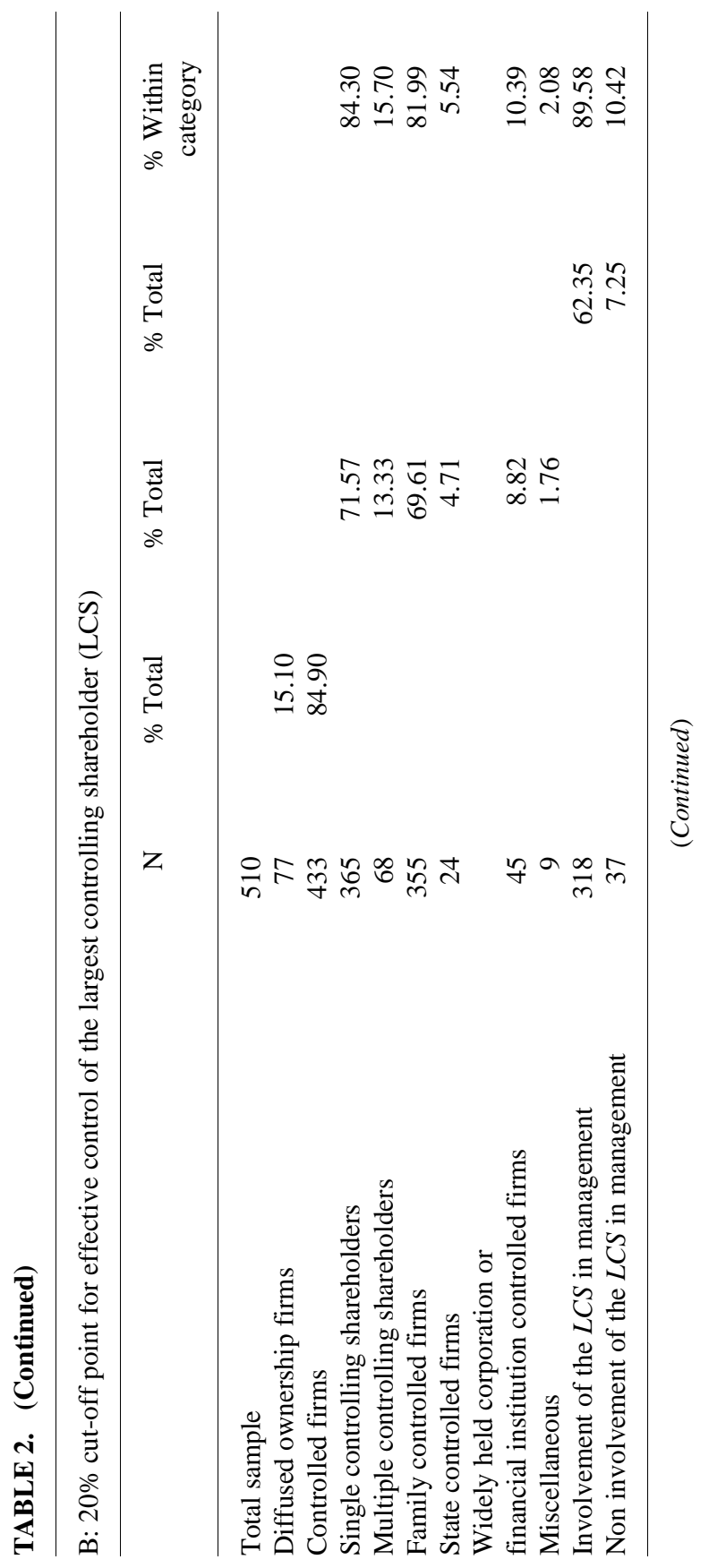




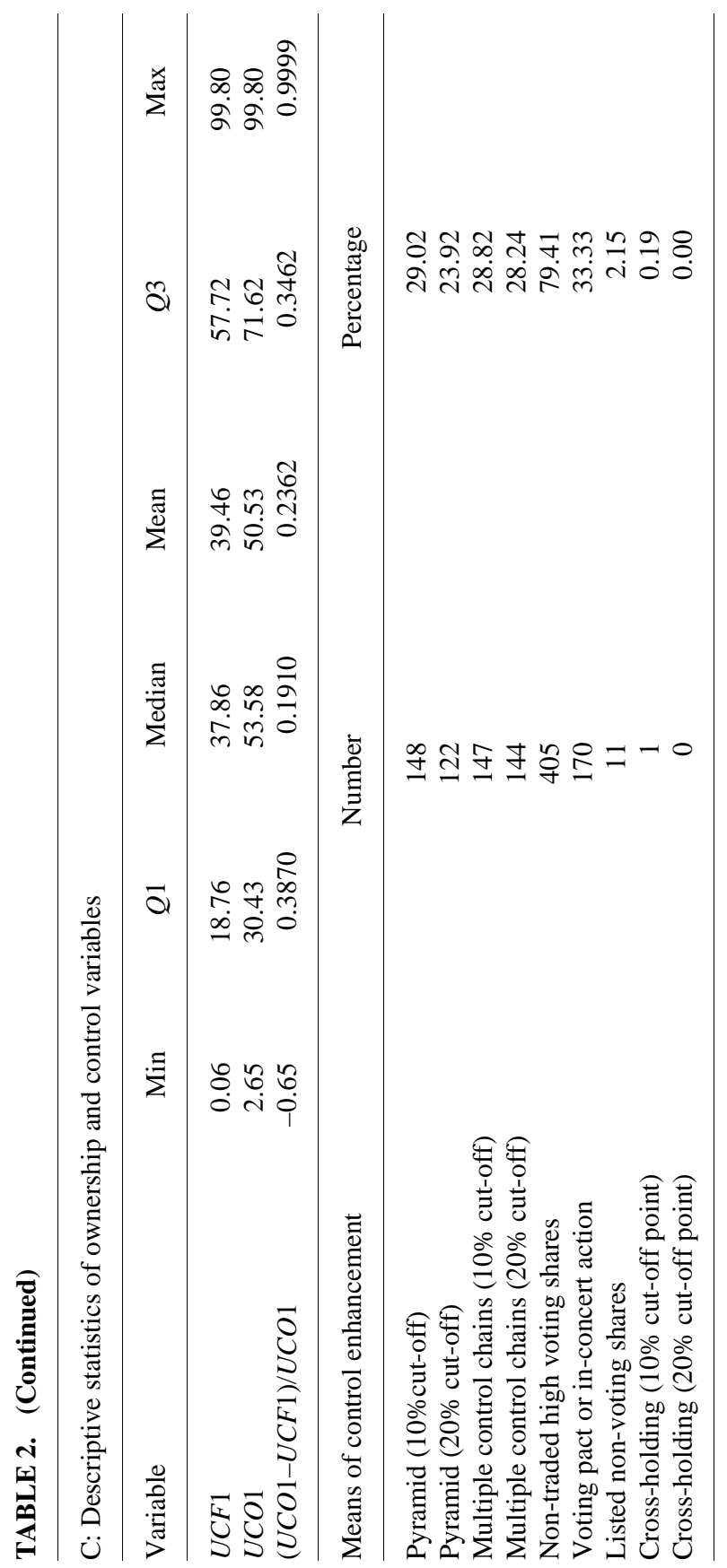


widely held. ${ }^{13}$ These figures are close to those of Faccio and Lang (2002) who report that $6.26 \%$ (14\%) of French firms are widely held based on 1997 data. The ultimate controlling shareholder is the unique controller in $60.59 \%$ (71.57\%) of the cases. Claessens, Djankov, and Lang (2000) reports figures as dramatic on average (67.80\%) as those in the present study for East Asian countries at $20 \%$ cut off point. Families are by far the dominant ultimate owner category in the sample. They represent $77.25 \%$ (71.57\%) of total firms in the sample. Out of 394 (355) family controlled firms, the controlling shareholder is member of the top management team in 338 (318) firms. This is true for $85.79 \%(89.58 \%)$ of the cases. Less than one tenth of the studied firms have a widely held corporation or a widely held financial institution as a controlling shareholder $9.02 \%$ (8.82\%). Finally, the state role is less important after the privatization wave that began in the mid-1980s. It controls only $6.10 \%$ (4.71\%) of the sample firms.

Panel $\mathrm{C}$ displays the ultimate cash flow rights $(U C F 1)$, the ultimate control rights (UCO1) and the excess control of the largest controlling shareholder as well as the different means used to enhance control. The largest ultimate controlling owner has $39.46 \%$ of the cash flow rights and $50.53 \%$ of the control rights. The excess control ratio measured by the control rights minus ownership rights of the largest ultimate controlling owner, all divided by his/her control rights ((UCO1-UCF1) / UCO1) is equal to $23.62 \%$ which is sharply higher than the reported ratio for the French case (7\%) in the Faccio and Lang's (2002) study. ${ }^{14}$ This ratio is also higher than the one for the Western European corporations (13.20\%) but is close to the Belgian (22.1\%) and Norwegian (22.4\%) cases and slightly lower than the one for East Asian corporations $(25.4 \%)$. This discrepancy comes about as a result of various devices, often simultaneously used, through which the main shareholder maintains grip on control. As a matter of fact, pyramids are used to control $29.92 \%(23.92 \%)$ of the sample firms at a $10 \%(20 \%)$ cut-off point. These figures are higher than those reported for all Western European countries except Norway (33.90\% at a 20\% level) but lower than East Asian economies (38.7\%). Also, controlling

13. Numbers in parentheses correspond to a $20 \%$ cut-off point.

14. This difference is mainly due to the fact that Faccio and Lang (2000) do not consider non-traded registered high voting shares - widely used among listed French firms - and do not trace pyramids back beyond unlisted firms, which jointly sharply understate the ownership-control discrepancy measure and give a sketchy description of ultimate owners (see Hamon [2001]). 
shareholders resort to multiple control chains in $28.82 \%$ (28.24\%) of the cases. The descriptive evidence shows that non-traded high voting shares are commonplace in France. In fact, $79.41 \%$ of sample firms confer a second vote to shareholders holding nominative stocks for, at least, a two-, three- or four-years period depending on firms' bylaws. Moreover, large shareholders often act in a formal concerted manner through binding explicit agreements. These agreements, drawn up for a given period, often compel any signatory shareholder to consult other cosignatory parts if he/she intends to sell his/her interests in the firm. Generally, pacts contain a pre-emptive rights clause giving pact members priority to buy shares of new issues. In one-third of the sample's cases, the controlling shareholders are tied by a pact agreement or in-concert action. We report that cross-holdings are next to inexistent (only one case corresponding to Sodexho Alliance at a 10\% threshold) and confirm the trivial use of the listed non-voting shares (11 firms out of 510 representing $2.15 \%$ ).

\section{B. Multivariate Analysis}

In this section the firm value proxied by the Tobin's $Q$ is explained by a set of ownership and control variables. ${ }^{15} \mathrm{We}$ introduce a set of controlling variables as surrogates of firm characteristics in all the regressions to avoid any spurious relation between firm value and the ownership and voting structure variables. We rely on previous research in considering the following variables: the natural logarithm of the book value of total assets as a proxy of firm's size, age measured as the number of years since the firm's establishment and leverage measured as the book value of non-equity liabilities over the book value of total assets. ${ }^{16}$ Also, we include sales growth proxied by the one-year percentage change in sales and the ratio of capital expenditure (including additions to fixed assets such as property, plant and equipment and investment in machinery and equipment) over book value of total assets as a proxy for growth prospects and investment opportunities. Industry dummies were intended to control for any industry effect on the valuation variable. We include 11 industry

15. The results across all the regression do not change qualitatively when the logarithmic transformation of the Tobin's $Q$ is used as a dependent variable suggesting the absence of spurious results due to extreme values.

16. The results remain qualitatively similar when the lagged leverage is used instead of the current leverage. 


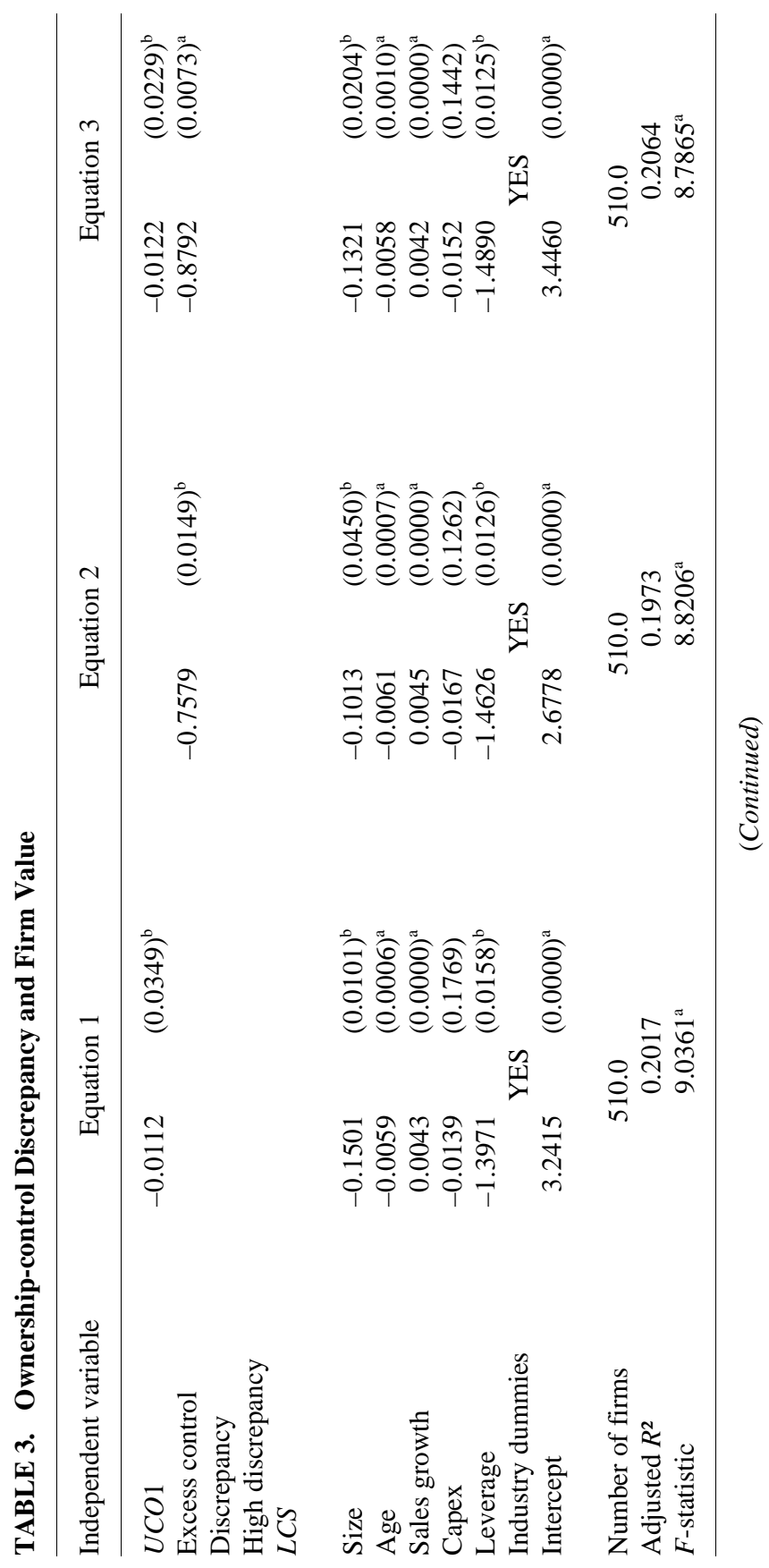




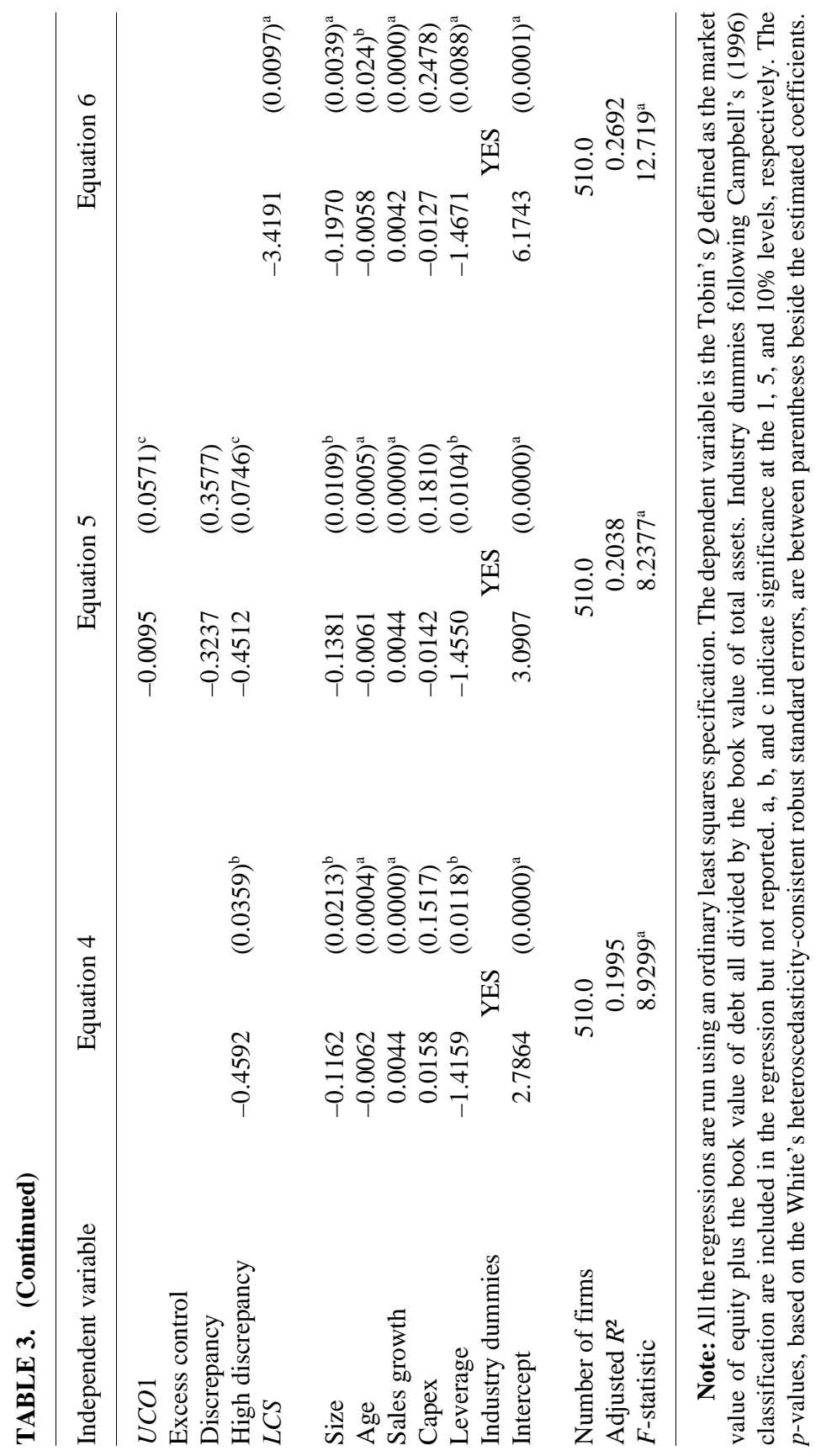


variables throughout the regressions following Campbell's (1996) classification with leisure as the reference industry. All variables used in the current study are presented in the appendix.

The Presence of the Largest Controlling Shareholder, Ownershipcontrol Discrepancy and Firm Value

The main concern of this study is to investigate whether greater concentration of the control rights in the hands of the controlling owners leads to more entrenchment, and thus increases their incentives and their capacity to extract private benefits. We also tried to inspect if a substantial discrepancy between ownership and control-due to lesser cash flow rights-exacerbates the likelihood for such expropriation. To test the possible existence of these two effects on minority expropriation, we regress the Tobin's $Q$ on the ultimate control right of the controlling shareholder (UCO1) and on the separation between his/her cash flow rights and control rights (Excess control). The latter variable is a proxy for the agency costs related to minority expropriation.

Table 3 presents multivariate analysis results of the relationship between the ownership and control of the largest controlling shareholder and firm value with both continuous and dummy variables proxying for the ownership-control discrepancy. Two dummies are used-discrepancy and high discrepancy - to capture a possible nonlinearity in the relationship. Discrepancy equals 1 if the ultimate control rights of the largest controlling shareholder (UCO1) are higher than his/her ultimate cash flow rights $(U C F 1)$ and 0 otherwise (See appendix). The control variables are the above-described firm characteristics and industry dummies. Before running any regression, the absence of multicollinearity is checked using variance inflation factors. Besides, we used the White (1980) formulation of a heteroskedasticity consistent covariance matrix estimator that provides correct estimates in the presence of heteroskedasticity of an unknown form.

In both regression 1 and 3 , we see a negative and statistically significant (at 5\% level) relationship between the largest shareholder control stakes (UCO1) and firm value. The two coefficients are economically similar. This outcome is not different from that of Cronqvist and Nilsson (2003) who, using Swedish data, find that the voting stakes of the controlling shareholders are negatively associated with Tobin's $Q$.

In the 2nd and 3rd regressions, we find that there is a negative influence of the controlling owner's excess control on firm valuation. The two coefficients for the discrepancy variable are consistently 
statistically and economically significant. The magnitude of the excess control coefficient $(-0.8792)$ is by far greater than that of the control stakes (-0.0122) suggesting that investors are more sensitive to the ownership-control discrepancy than to the actual level of control maintained by the largest controlling shareholder per se. The coefficients of the controlling variables barely change from one regression to another.

In sum, the results support hypothesis I. This negative effect may also be explained by the fact that firms with greater discrepancy between ownership and control are traded at much greater discount than are other firms. ${ }^{17}$ These results mean that any decision that increases the discrepancy between the ownership and control would have a heavily negative impact on the firm value. Amidst others, the following decisions sharpen that discrepancy: 1 / granting a second vote to the controlling shareholder, 2 / converting non-voting shares into voting shares, 3 / buying-back shares within a repurchase program initiated by the firm itself because those repurchased shares are deprived from voting. Contrariwise, dual class unification when superior vote shareholders give up their superior voting status would positively affect the firm value.

In the next regression (4), we use a discrepancy dummy, high discrepancy, which takes the value of one if the ultimate control rights of the largest controlling shareholder (UCO1) are higher than his/her cash flow rights (UCF1) and his/her excess control (UCO1 - UCF1) / $U C O 1$ is higher than the median excess $(19.10 \%)$ in corporations where ownership differs from control, and zero otherwise. This variable is significantly negatively related to the firm value (5\% threshold). The economic effect of this variable is substantially important (-0.4592) and suggests that firms with great discrepancy level trade at larger discount than others. In an unreported regression, a discrepancy dummy, which takes the value of one if control rights exceed cash flow rights and zero otherwise was used as the unique ownership variable. Its coefficient was negative but not significant. The non-significance may be due to firms where excess control hardly exists. These results are consistent with those of Claessens et al. (2002) who found that East Asian firms featuring a discrepancy between ownership and control are traded at a discount that is positively related to the magnitude of such discrepancy.

In a specification close to that of Claessens et al. (2002) (regression 5), where two dummies were included (high discrepancy and

17. The Durbin-Wu-Hausman test shows no reverse causality in the relationship between Tobin's $Q$ and the discrepancy between ownership and control. Claessens et al. (2002) consistently argue that controlling shareholders are unlikely to adjust quickly and frequently their ownership structure to temporary changes in firm valuation. 


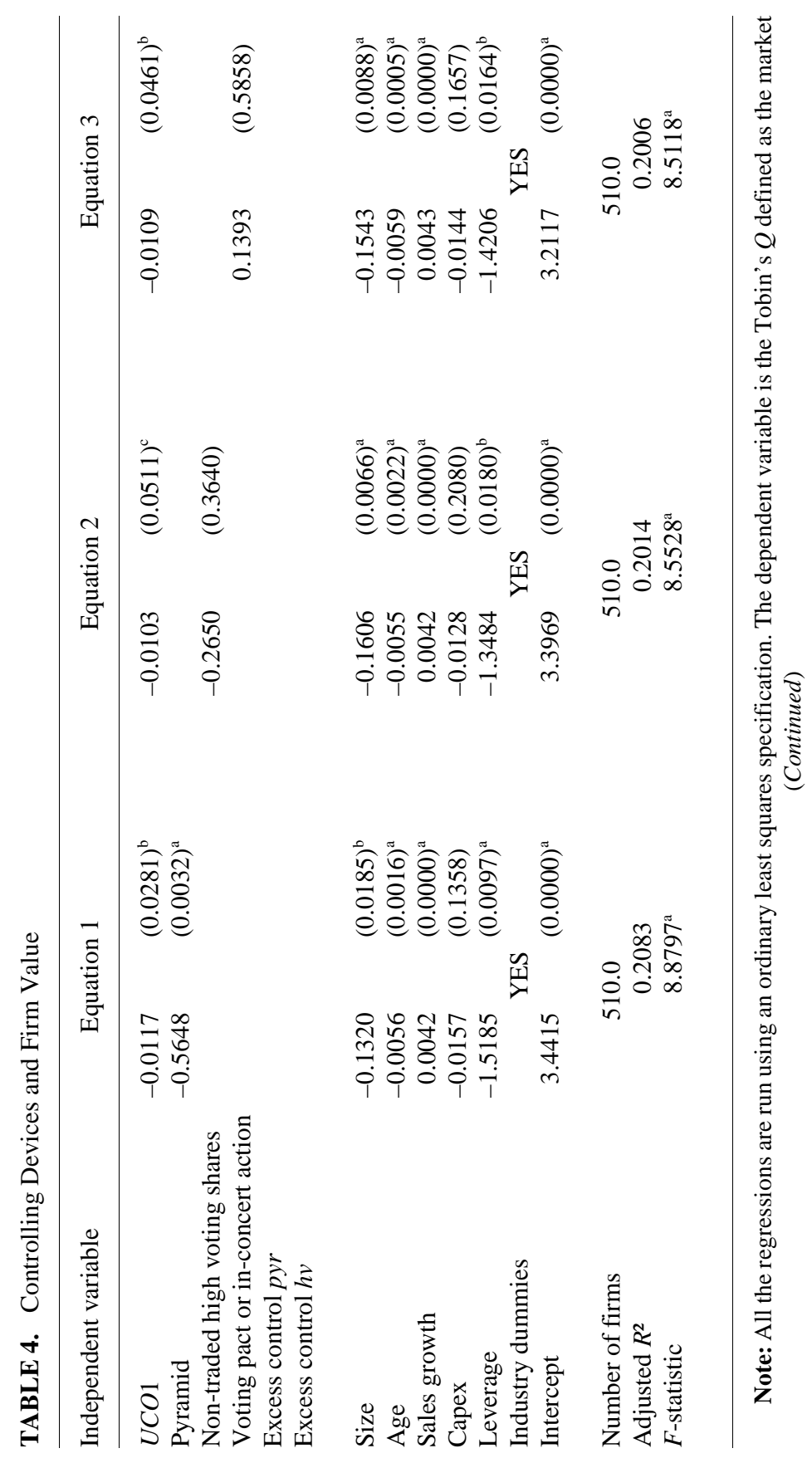




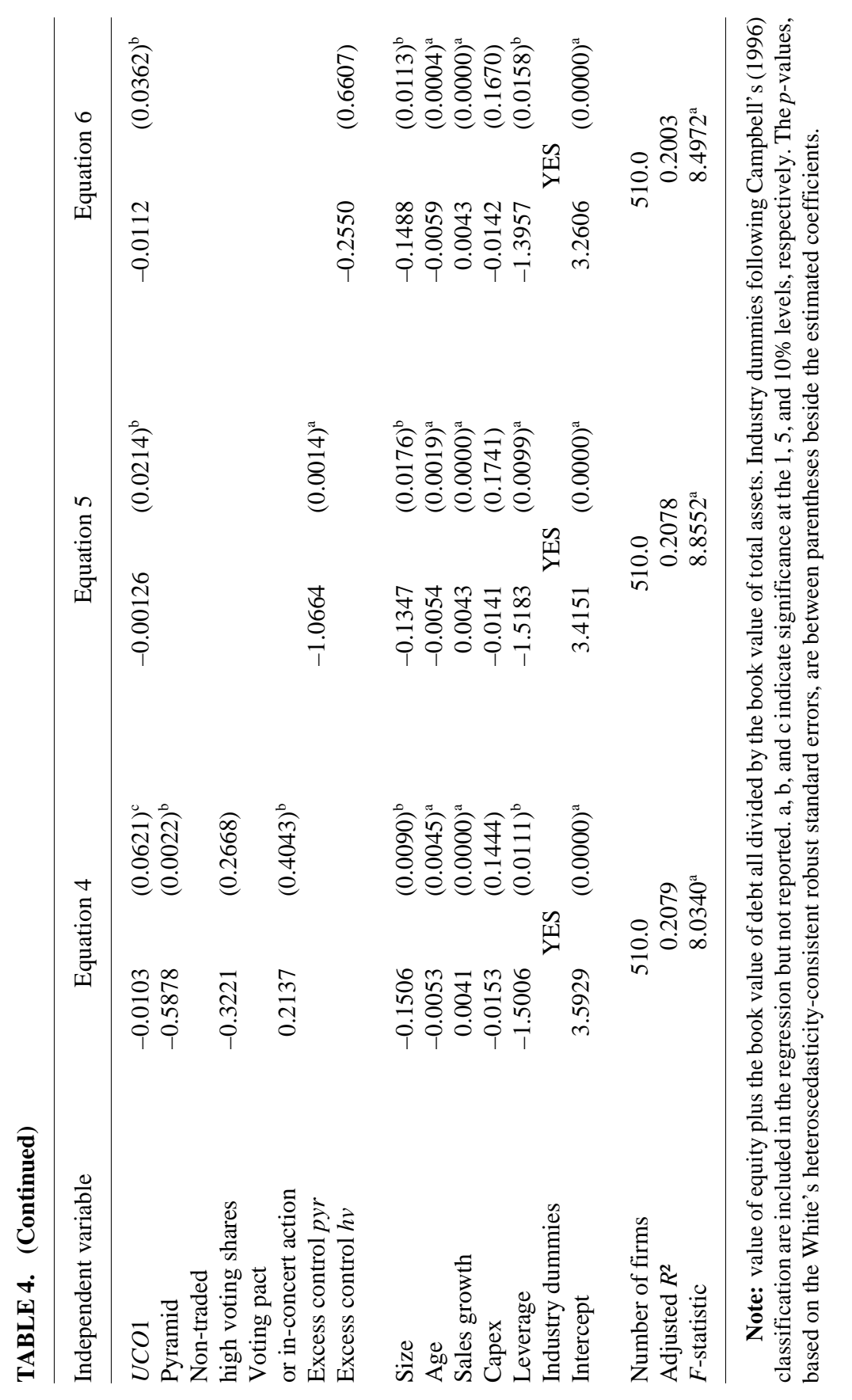


discrepancy), the coefficient of the later was negative and insignificant while the coefficient of the former was negative and significant at only a $10 \%$ level this time. All but one of the controlling variables have significant effect on firm value. The firm's size and age have a negative influence on its valuation indicating that small-sized and younger firms may have more growth perspectives. Sales growth, a proxy for future growth opportunities, positively affects the Tobin's $Q$, whereas leverage shows a negative influence.

The effect of the presence of the large controlling shareholder is assessed in regression 6 through a dummy variable $L C S$ which equals 1 if the firm is controlled at $10 \%$ cut-off point and 0 otherwise. The estimated coefficient is negative and significant at the $1 \%$ threshold. This outcome suggests that controlled firms are valued at a discount in comparison with widely held firms. An important caveat on this result that should be interpreted cautiously is the small number of widely held firms in the current sample (28 firms).

\section{The Effect of Control Devices on Firm Value}

Up to now the findings do not provide any enlightenment concerning the devices that bring about value discounts. The regressions in table 4 are aimed to investigate the effect of control mechanisms on the firm value. To do so, three dummies were created: Pyramid, ${ }^{18}$ Non-traded high voting shares and Voting pact or in-concert action. ${ }^{19}$ Any of these dummies equals one when the firm has implemented the device, and zero otherwise. We regress the Tobin's $Q$ on these dummies while controlling for voting structure, firm characteristics and industry differences. The rationale underlying these regressions is that minority shareholders anticipate the extent of the expropriation behavior of the ultimate owner using any of the enumerated devices, gauge the likelihood of being trapped and discount the firm value in consequence.

The coefficient of pyramiding dummy variable in regression 1 (table 4) is negative and statistically significant at one percent threshold, which indicates that firms appertaining to a pyramid are markedly

18. A firm is considered as affiliated to a pyramid when it has an ultimate controlling owner who controls it through another partially owned corporation.

19. We do not distinguish here between voting pact and in-concert action. Both non-traded high shares dummy and voting pact or in-concert action dummy are multiplied by controlling shareholder dummy to consider only the controlled firms. Scarcely used mechanisms - i.e., voting cap and listed non-voting shares - are left out from the analysis. 
discounted in comparison with unaffiliated ones. The magnitude of the coefficient $(-0.5648)$ reflects that ceteris paribus a pyramid-affiliated firm is worth less than half of an unaffiliated firm (hypothesis II). In the following regression (no. 2 in table 4 ), the non-traded high voting shares dummy's coefficient is negative but insignificant. That is, the evidence loosely supports the argument that the use of non-traded high voting shares is detrimental to the firm value (hypothesis III). In contrast to those two mechanisms, no evidence on the effect of the use of voting pact or in-concert action is tracked down. The coefficient of this dummy is insignificantly positive (regression 3 in table 4 ). When combining the three dummies in the same regression, results remain unchanged (regression 4 in table 4). We deepen the analysis by considering the actual ownership-control discrepancy resulting from pyramiding (Excess control pyr) and that resulting from non-traded high voting shares (Excess control $h v$ ) instead of using dummy variables. ${ }^{20}$ The current study pioneers the computation of these two variables (See figure 1 in section II for details on the computation method). Two additional regressions were consequently added. The results of these regressions (regression 5 and 6 in table 4) are consistent with the existing findings. Excess control pyr impacts negatively and significantly the firm value whereas Excess control $h v$ influences negatively but insignificantly the firm value. In sum, the evidence suggests that the affiliation to pyramids leads to a more entrenched situation associated with value discounts. Pyramiding seems to be the most detrimental controlling device to minority shareholders. Such a device is propitious to tunneling activity in that it eases channeling resources to firms located at the very top of the pyramid. These more tightly-owned firms may benefit from favorable loan terms when dealing with lower tier firms within the pyramid internal capital market. These results are in accordance with those of Attig, Fischer and Gadhoum (2003), and are in contrast with those of Claessens et al. (2002) who found that the value discount is driven by the ownershipcontrol discrepancy and not by any controlling mechanism per se.

The Effect of the Large Controlling Shareholder Type and Involvement in the Management

In view of the above evidence that supports a significant negative effect of ownership-control discrepancy on firm value, we investigate whether

20. We are indebted to an anonymous referee for bringing this point to our attention. 
TABLE 5. Controlling Shareholders' Type, Management Involvement and Firm Value

\begin{tabular}{|c|c|c|c|c|}
\hline \multirow{3}{*}{$\frac{\text { Independent variable }}{U C O 1}$} & \multirow{2}{*}{\multicolumn{2}{|c|}{$\frac{\text { All the sample }}{\text { Equation } 1}$}} & \multirow{2}{*}{\multicolumn{2}{|c|}{$\frac{\text { Family firms sample }}{\text { Equation } 2}$}} \\
\hline & & & & \\
\hline & -0.0116 & $(0.0376)^{\mathrm{b}}$ & -0.0137 & $(0.0920)^{c}$ \\
\hline LCS Family & 0.0387 & $(0.9191)$ & & \\
\hline \multicolumn{5}{|l|}{ LCS Family $\times$} \\
\hline Excess control & -0.7042 & $(0.0095)^{\mathrm{a}}$ & & \\
\hline LCS State & -0.2441 & $(0.5734)$ & & \\
\hline \multicolumn{5}{|l|}{ LCS State $\times$} \\
\hline Excess control & -2.2968 & $(0.0377)^{\mathrm{b}}$ & & \\
\hline LCS WHFFI & 0.6452 & $(0.5498)$ & & \\
\hline \multicolumn{5}{|l|}{ LCS WHFFI $\times$} \\
\hline Excess control & -1.4605 & $(0.3691)$ & & \\
\hline Family membership & & & 0.7693 & $(0.0209)^{\mathrm{b}}$ \\
\hline \multicolumn{5}{|l|}{ Family membership $\times$} \\
\hline Excess control & & & -0.4459 & $(0.4130)$ \\
\hline Size & -0.1188 & $(0.0492)^{\mathrm{b}}$ & -0.0920 & $(0.1920)$ \\
\hline Age & -0.0062 & $(0.0005)^{\mathrm{a}}$ & -0.0055 & $(0.0069)^{a}$ \\
\hline Sales growth & 0.0041 & $(0.0000)^{\mathrm{a}}$ & 0.0044 & $(0.0730)^{c}$ \\
\hline Capex & -0.0141 & $(0.1870)$ & -0.0159 & $(0.1205)$ \\
\hline Leverage & -1.5416 & $(0.0121)^{b}$ & -1.4783 & $(0.0289)^{\mathrm{b}}$ \\
\hline Industry dummies & \multicolumn{2}{|c|}{ YES } & \multicolumn{2}{|c|}{ YES } \\
\hline Intercept & 3.3091 & $(0.0000)^{\mathrm{a}}$ & 2.6470 & $(0.0000)^{a}$ \\
\hline Number of firms & \multicolumn{2}{|c|}{510.0} & \multicolumn{2}{|c|}{394.0} \\
\hline Adjusted $R^{2}$ & \multicolumn{2}{|c|}{0.2051} & \multicolumn{2}{|c|}{0.1534} \\
\hline$F$-statistic & \multicolumn{2}{|c|}{$6.9701^{\mathrm{a}}$} & \multicolumn{2}{|c|}{$4.9573^{\mathrm{a}}$} \\
\hline
\end{tabular}

Note: All the regressions are run using an ordinary least squares specification. Regression 2 is run on the family firms' sub-sample. The dependent variable is the Tobin's $Q$ defined as the market value of equity plus the book value of debt all divided by the book value of total assets. Industry dummies following Campbell's (1996) classification are included in the regression but not reported. a, b, and c indicate significance at the 1,5 , and $10 \%$ levels, respectively. The $p$-values, based on the White's heteroscedasticity-consistent robust standard errors, are between parentheses beside the estimated coefficients.

the identity of the controlling shareholder matters in explaining differences in corporate valuation. We also test the effect of the ownership-vote discrepancy of each controlling shareholder category on the Tobin's $Q$. To do so, controlling owners were broken down into 
three categories: Family, State and widely held firm or widely held financial institution. Specifically, three dummy variables (LCS Family, LCS State, and LCS WHFFI) are included in the regression (regression 1 in table 5) each of which corresponding to one shareholder category. In addition, we combine the three dummy variables representing owner types and the excess control (LCS Family $\times$ Excess control, LCS State $\times$ Excess control, and LCS WHFFI $\times$ Excess control) to take into consideration the effect of the ownership-control discrepancy for each specific owner category. The results displayed in table 5 are somewhat striking and present evidence that the detrimental effect of the discrepancy is exacerbated when the firm is state-owned or family owned. All the controlling owner category's dummies are statistically insignificant suggesting that the excess control is what matters and not the controlling owner's identity per se.

In regression 2 (table 5), we delve into family controlled firms to investigate the effect of taking part in management by the controlling shareholder. A family membership dummy equal to 1 , if the large controlling shareholder is present among firm's top management (CEO, honorary chairman, chairman, or vice-chairman) and 0 otherwise, is included in the equation. The same variable is interacted with excess value. Are considered as members of the same family those with the same surname and in-law relatives. The evidence shows that there is a positive effect of the membership of the controlling shareholder to the management whereas the interaction variable affects negatively but insignificantly the firm value.

\section{Multiple Controlling Shareholders}

While the above results support the entrenchment effect of the largest controlling shareholder, especially when there is a discrepancy between ownership and control stakes, they do not provide any evidence on the effect of a second largest controlling shareholder. Regressions in table 6 explore the net effect of a shared control situation (hypothesis IV). Up to now, only a few studies have addressed empirically the issue of shared control and to the best of our knowledge, this issue has been ignored in the context of pyramiding.

There seems to be no unique voting measure of the second largest shareholder stakes that could be applied to all the situations encountered in our sample. The ratio of ultimate control (UCO2 / UCO1) as a measure of the power of the second largest shareholder in comparison 


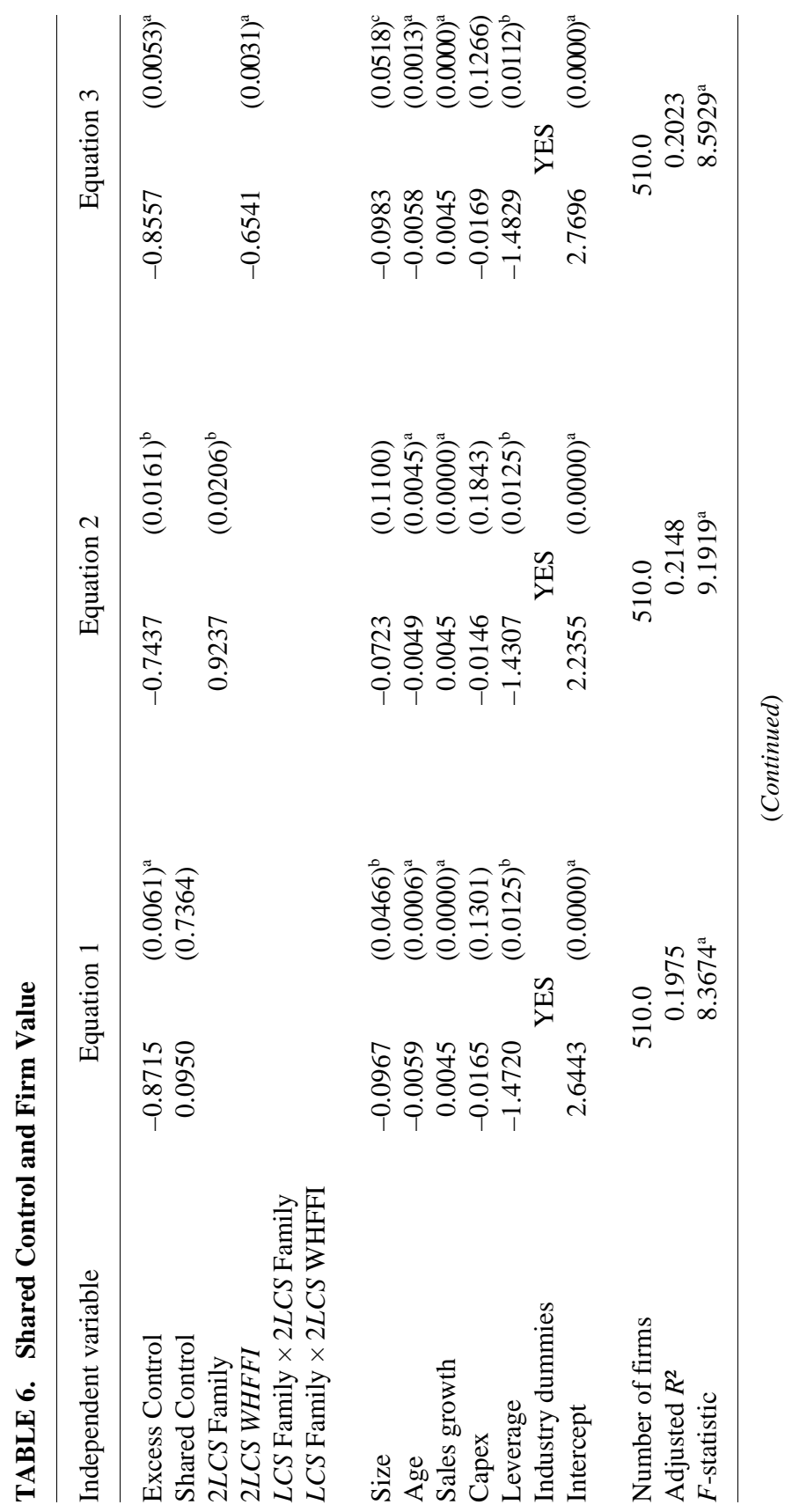




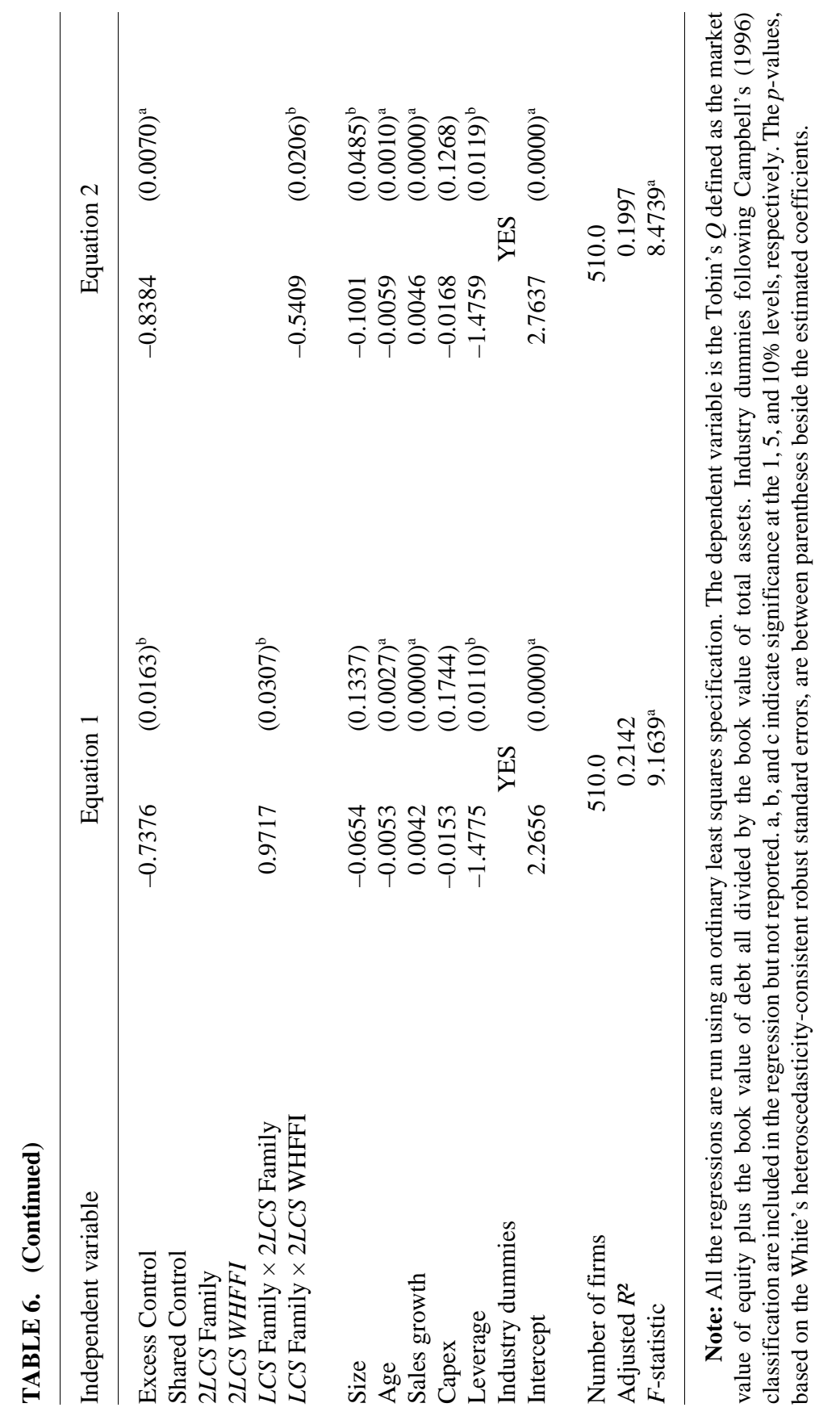


to that of the largest one may be inappropriate when applied to some situations, where UCOi denotes the ultimate control rights of the $i^{\text {th }}$ largest shareholder. As an example, let's consider the case where two firms $\mathrm{X}$ and $\mathrm{Y}$ control a firm $\mathrm{Z}$ with $45 \%$ and $35 \%$ of voting stakes respectively. The unique controlling shareholder of $\mathrm{X}$ is family $F 1(25 \%$ of the voting stakes) and the unique controlling shareholder of $\mathrm{Y}$ is family $F 2$ ( $40 \%$ of the voting stakes). According to the commonly used method of analysis, we follow the largest link in the control chain to detect the largest controlling shareholder. Hence, family $F 1$ is the largest controlling shareholder of $\mathrm{Z}$ with $U C O 1=25 \%$ and the second largest controlling shareholder is family $F 2$ with $U C O 2=35 \%$. Despite the fact that the control of firm Z is obviously shared, the use of (UCO2 / UCO1) leads to a spurious figure (greater than 1). ${ }^{21}$ To remedy to similar cases, we use a dummy variable shared control that could be applied to all situations without restriction. This dummy equals 1 if the firm has a second largest shareholder at $10 \%$ threshold and 0 otherwise. For each firm, we check that direct shareholders are not under the control of the same entity.

Each regression in this part contains excess control and shared control as ownership variables. Other firm characteristics and industry dummies are included. At a first glance, the presence of a second controlling shareholder does not affect firm valuation. The coefficient of shared control equals 0.095 and is statistically insignificant. Insofar as the outcome of a shared control might vary with the identity of the second largest controlling shareholder (depending on its role: monitoring or colluding), the insignificant effect of the shared control variable might be due to two combined opposing effects. The control is shared in 173 firms representing 33.92\% of the sample's firms. The second controlling shareholder is a family in 115 firms, a widely held firm or financial institution in 51 firms, and the state in 5 firms. The firm employees are the second controlling shareholder in the two remaining cases. In the two following regressions (regression 2 and 3), we include two dummy variables namely $2 L C S$ Family and $2 L C S$ WHFFI to control for the identity of the second largest controlling

21. The ratio of direct voting ( $V 2 / V 1$ where $V i$ is the direct voting stake of the $i^{\text {th }}$ largest controlling shareholder) as a measure for weighing the second largest shareholder voting power relative to the largest one is not always appropriate. Suppose that a firm A is controlled by two firms B and C with $45 \%$ and $35 \%$ voting stakes respectively, and that a family is the unique controlling shareholder of both B and C with a $40 \%$ voting stakes each. Since B and $\mathrm{C}$ are under the control of the same entity, considering them as distinct is incorrect and consequently the use of $V 2 / V 1$ when studying the relative power in firm $\mathrm{A}$ is inappropriate. 
shareholder when he/she is a family or a widely held firm or financial institution respectively. Regression 2 results show a positive and statistically and economically significant effect when the control is shared with a family but a negative impact when the control is shared with a widely held firm or financial institution (regression 3 ) regardless of the type of the largest controlling shareholder. This result suggests that families, when sharing control, monitor the largest controlling shareholder limiting, thus, minority expropriation. On the other hand, widely held firms or financial institutions collude exacerbating rent-extraction behavior. The same conclusions remain valid when we run similar regressions while fixing the largest controlling shareholder as a family (regression 4 and 5).

\section{Conclusion}

Using a sample of 510 French listed firms, this paper addresses the agency conflict between large and minority shareholders. The key findings are that the large controlling shareholder's control stakes per se, and notably along with ownership-control discrepancy, detrimentally affect the firm value. The magnitude of the discrepancy's negative effect sharply outweighs that of the control stakes' size of the large controlling shareholder. These results are in consistence with the entrenchment effect hypothesis. Additional analysis suggests that controlling shareholders resort to-in a decreasing order of prevalence-non-traded high voting shares, voting pact or in-concert action and pyramiding to maintain control. Pyramiding and non-traded high voting shares are shown to lead to value discounts. Only the coefficient of the former device is statistically significant. The findings do not support the contention that the ownership types influence the firm valuation. In contrast, we find that family-controlled firms and state-owned firms controlled with a wedge between control rights and cash flow rights are discounted in comparison with other firms. Regardless of the controlling shareholder's identity; sharing control with a family constrains the former to maximize the firm value. However sharing control with a widely held firm or with a financial institution fosters this self-serving behavior.

Although the results documented in this paper plainly scratch the thorny concern of the agency conflicts between a large controlling shareholder and minority shareholders, they might be useful for lawmakers concerned with the protection of small shareholders, in the 
implementation of corporate governance best practices and in safeguarding trust in financial markets, especially in gloomy periods. The current research might be extended in various directions. The composition of the board of directors and the interlocking directorate within pyramids are worth studying to ferret out the extent of power vested in the ultimate controlling shareholder.

Appendix. Description of Variables Used in This Study

\begin{tabular}{|c|c|}
\hline Variable & Description \\
\hline \multicolumn{2}{|l|}{ Dependent variable } \\
\hline Tobin's $Q$ & $\begin{array}{l}\text { (Market value of equity }+ \text { Book value of debt) / Book } \\
\text { value of total assets }\end{array}$ \\
\hline \multicolumn{2}{|l|}{ Independent variables } \\
\hline$U C F 1$ & Ultimate cash flow rights of the $L C S$. \\
\hline UCO1 & Ultimate control rights of the $L C S$. \\
\hline Excess control & $\begin{array}{l}\text { Excess control is the ownership-control discrepancy } \\
\text { measure of the largest controlling shareholder. It is } \\
\text { measured as }(U C O 1-U C F 1) / U C O 1 \text {. }\end{array}$ \\
\hline Excess control pyr & $\begin{array}{l}\text { Excess control pyramiding is the ownership-control } \\
\text { discrepancy measure of the largest controlling shareholder } \\
\text { due to pyramiding. It is measured as (UCO1pyr - } \\
\text { UCF 1 pyr) / UCO1pyr. (See figure } 1 \text { ) }\end{array}$ \\
\hline Excess control $h v$ & $\begin{array}{l}\text { Excess control hv is the ownership-control discrepancy } \\
\text { measure of the largest controlling shareholder due to } \\
\text { non-traded high voting shares. It is measured as (Excess } \\
\text { control - Excess control pyr). (See figure } 1 \text { ) }\end{array}$ \\
\hline Discrepancy & $\begin{array}{l}\text { Dummy equals } 1 \text { if the ultimate control rights of the largest } \\
\text { controlling shareholder are higher than his/her ultimate } \\
\text { cash flow rights; and } 0 \text { otherwise. }\end{array}$ \\
\hline High discrepancy & $\begin{array}{l}\text { Dummy equals } 1 \text { if control rights }(U C O 1) \text { are higher than } \\
\text { cash flow rights }(U C F 1) \text { and the excess }(U C O 1-U C F 1) / \\
U C O 1 \text { is higher than the median excess in corporations } \\
\text { where ownership differs from control; and } 0 \text { otherwise. }\end{array}$ \\
\hline $\begin{array}{l}\text { Large controlling } \\
\text { shareholder }(L C S)\end{array}$ & $\begin{array}{l}\text { Dummy equals } 1 \text { if the firm is controlled at } 10 \% \\
\text { cut-off point; and } 0 \text { otherwise. }\end{array}$ \\
\hline Pyramid & $\begin{array}{l}\text { Dummy equals } 1 \text { if the firm is controlled through a } \\
\text { pyramid; } 0 \text { otherwise. A firm is controlled through a } \\
\text { pyramid if it has an ultimate owner, who controls it } \\
\text { indirectly through another partially held corporation. }\end{array}$ \\
\hline
\end{tabular}

(Continued) 
Appendix. (Continued)

\begin{tabular}{ll}
\hline Variable & Description \\
\hline $\begin{array}{l}\text { Non-traded high } \\
\text { voting shares }\end{array}$ & $\begin{array}{l}\text { Dummy equals } 1 \text { if the firm's bylaw authorizes the } \\
\text { existence of non-traded high voting shares; } 0 \\
\text { otherwise. } \\
\text { Dummy equals } 1 \text { if there is an agreement between } \\
\text { the large controlling shareholders (voting pact or in } \\
\text { in-concert action } \\
\text { concert action); } 0 \text { otherwise. }\end{array}$ \\
LCS Family & $\begin{array}{l}\text { Dummy equals } 1 \text { if the } L C S \text { is a family; and } 0 \\
\text { otherwise. } \\
\text { Dummy equals } 1 \text { if the } L C S \text { is the state; and } 0 \\
\text { otherwise. } \\
\text { Dummy equals } 1 \text { if the } L C S \text { is a widely held firm or a } \\
\text { widely held financial institution; and } 0 \text { otherwise. }\end{array}$ \\
Family membership & $\begin{array}{l}\text { Dummy equals } 1 \text { if the } L C S \text { (or a member of his } \\
\text { family) is present among firm's top management } \\
\text { (CEO, honorary chairman, chairman, or }\end{array}$ \\
vice-chairman); and 0 otherwise. \\
Dummy equals 1 if the firm has a second shareholder \\
at $10 \%$ threshold; and 0 otherwise. \\
Duared control
\end{tabular}

\section{References}

Anderson, R. C.; Mansi, S. A.; and Reeb, D. M. 2003. Founding family ownership and the agency cost of debt. Journal of Financial Economics 68(2): 263-285.

Anderson, R. C., and Reeb, D. M. 2003. Founding-family ownership and firm performance: Evidence from S\&P 500. Journal of Finance 58(3): $1301-1327$.

Attig, N.; Fischer, K.; and Gadhoum, Y. 2003. On the determinants of pyramidal ownership: Evidence on dilution of minority interests. Mimeo. 
Barca, F., and Becht, M. 2001. The Control of Corporate Europe. Oxford: Oxford University Press.

Bebchuk, L. 1999. A rent-protection theory of corporate ownership and control. NBER working paper no. 7203. Cambridge, Mass.: National Bureau of Economic Research.

Bebchuk, L.; Kraakman, R.; and Triantis, G. 2000. Stock pyramids, cross-ownership, dual-class equity: The creation of agency costs of separating control from cash flow rights. In R. K. Morck (eds). Concentrated Corporate Ownership. Chicago, I1. University of Chicago Press.

Bennedsen, M., and Wolfenzon, D. 2000. The balance of power in closely held corporations. Journal of Financial Economics 58(1/2): 113-139.

Berle, A., and Means, G. 1932. The Modern Corporation and Private Property. New York: MacMillan.

Bertrand, M.; Mehta, P.; and Mullainathan, S. 2002. Ferreting out tunneling: an application to Indian business groups. The Quarterly Journal of Economics 117(1): 121-148.

Bianchi, M.; Bianco, M.; and Enriques, L. 2001. Pyramidal groups and the separation between ownership and control in Italy. In F. Barca and M. Becht (eds). The Control of Corporate Europe. Oxford: Oxford University Press.

Bloch, F., and Hege, U. 2002. Multiple shareholders and control contests. Unpublished working paper. Paris: HEC.

Bloch, L., and Kremp, E. 2001. Ownership and voting power in France. In F. Barca and M. Becht (eds). The Control of Corporate Europe. Oxford: Oxford University Press.

Boehmer, E. 2000. Business groups, bank control, and large shareholders: An analysis of German takeovers. Journal of Financial Intermediation 9(2): 117-148.

Bolton, P., and Von Thadden, E. 1998. Blocks, liquidity and corporate control. Journal of Finance 53(1): 1-25.

Burkart, M.; Gromb, D.; and Panunzi, F. 1997. Large shareholders, monitoring, and the value of the firm. Quarterly Journal of Economics 112(3): 693-728.

Campbell, J. 1996. Understanding risk and return. Journal of Political Economy 104(2): 298-345.

Claessens, S.; Djankov, S.; and Lang, L. H. P. 2000. The separation of ownership and control in East Asian corporations. Journal of Financial Economics 58(1/2), 81-112.

Claessens, S.; Djankov, S.; Fan, J. P. H.; and Lang, L. H. P. 2002. Disentangling the incentive and entrenchment effects of large shareholdings. Journal of Finance 57(6): 2741-2771.

Cronqvist, H., and Nilsson, M. 2003. Agency costs of controlling shareholders. Journal of Financial and Quantitative Analsysis 38(4): 695-719.

Daily, C. M., and Dollinger, M. J. 1992. An examination of ownership structure in family and professionally managed firms. Family Business Review 5(2): 117-137. 
Daily, C. M., and Thompson, S. S. 1994. Ownership structure, strategic posture, and firm growth: An empirical examination. Family Business Review 7(3): 237-249.

DeAngelo, H., and DeAngelo, L. 1985. Managerial ownership of voting rights: A study of public corporations with dual classes of common stock. Journal of Financial Economics 14(1): 33-69.

DeAngelo, H., and DeAngelo, L. 2000. Controlling stockholders and the disciplinary role of corporate payout policy: A study of the Times Mirror Company. Journal of Financial Economics 56(2): 153-207.

Faccio, M., and Lang, L. H. P. 2002. The ultimate ownership of Western European corporations. Journal of Financial Economics 65(3): 365-395.

Faccio, M.; Lang, L. H. P.; and Young, L. 2001. Dividends and expropriation. American Economic Review 91(1): 54-78.

Fama, E. F., and Jensen, M. C. 1983. Separation of ownership and control. Journal of Law and Economics 26(2): 301-325.

Gérard, C. 2001. L'activisme des actionnaires minoritaires au sein du gouvernement des entreprises Françaises. Unpublished Ph.D. thesis. Université de Bourgogne.

Ginglinger, É., and L'Her, J-F. 2006. Ownership structure and open market stock repurchases in France. The European Journal of Finance 12 (1): 77-94.

Gomes, A. R., and Novaes, W. 2001. Sharing of control as a corporate governance mechanism. PIER Working paper 01-029. University of Pennsylvania Law School.

Grossman, S. J, and Hart, O. D. 1988. One share-one vote and the market for corporate control. Journal of Financial Economics 20(1/2): 175-202.

Hamon, J. 2001. La répartition des droits de vote, leur exercice et l'efficacité économique. Revue d'Économie Financière 63: 175-209.

Holderness, C. G.; Kroszner, R. S.; and Sheehan, D. P. 1999. Were the good old days that goods? Changes in managerial stock ownership since the great depression. Journal of Finance 54(2): 435-470.

Holderness, C. G., and Sheehan, D. P. 1988. The role of majority shareholders in publicly held corporations: An explanatory analysis. Journal of Financial Economics 20(1/2): 317-346.

Hölmstrom, B., and Tirole, J. 1993. Market liquidity and performance monitoring. Journal of Political Economy 101(4): 678-709.

James, H. S. Jr. 1999. Owner as manager, extended horizons and the family firm. International Journal of the Economics of Business 6(1): 41-56.

Johnson, S.; Boone, P.; Breach, A.; and Friedman, E. 2000a. Corporate governance in the Asian financial crisis. Journal of Financial Economics 58(1/2): 141-186.

Johnson, S.; La Porta, R.; Lopez-de-Silanes, F.; and Shleifer, A. 2000b. Tunneling. American Economic Review Papers and Proceedings 90(2): 22-27.

La Porta, R.; Lopez-de-Silanes, F.; and Shleifer, A. 1998. Law and finance. 
Journal of Political Economy 106(6): 1113-1155.

La Porta, R.; Lopez-de-Silanes, F.; and Shleifer, A. 1999. Corporate ownership around the World. Journal of Finance 54(2): 471-517.

La Porta, R.; Lopez-de-Silanes, F.; Shleifer, A.; and Vishny, R. W. 2000. Investor protection and corporate governance. Journal of Financial Economics 58(1/2): 3-27.

Lehman, E., and Weigand, J. 2000. Does the governed corporation perform better? Governance structures and corporate performance in Germany. European Finance Review 4(2): 157-195.

Maug, E. 1998. Large shareholders as monitors: Is there a tradeoff between liquidity and control? Journal of Finance 53(1): 65-98.

Maury, C. B., and Pajuste, A. 2005. Multiple large shareholders and firm value. Journal of Banking and Finance 29(7): 1813-1834.

Megginson, W. L.; Nash, R. C.; and Van Randenborgh, M. 1994. The financial and operating performance of newly privatized firms: An international empirical analysis. Journal of Finance 49(2): 403-452.

Mitton, T. 2002. A cross-firm analysis of the impact of corporate governance on the East Asian financial crisis. Journal of Financial Economics 64(2): 215-241.

Morck, R.; Shleifer, A.; and Vishny, R. W. 1988. Management ownership and market valuation: An empirical analysis. Journal of Financial Economics 20(1/2): 293-315.

Muus, K. 1998. Non-voting shares in France: An empirical analysis of the voting premium. Working Paper Series, Goethe University Frankfurt am Main.

Shleifer, A., and Vishny, R. W. 1986. Large shareholders and corporate control. Journal of Political Economy 94(3): 461-488.

Shleifer, A., and Vishny, R. W. 1997. A survey of corporate governance. Journal of Finance 52(2): 737-783.

Smith., B. F., and Amoako-Adu, B. 1999. Management succession and financial performance of family controlled firms. Journal of Corporate Finance 5(4): 341-368.

Stulz, R. 1988. Managerial control of voting rights: Financing policies and the market for corporate control. Journal of Financial Economics 20(1/2): $25-54$.

White, H. 1980. A heteroskedasticity-consistent covariance matrix estimator and a direct test for heteroskedasticity. Econometrica 48(4): 817-838.

Wiwattanakantang, Y. 2001. Controlling shareholders and corporate value: Evidence from Thailand. Pacific-Basin Finance Journal 9(4): 323-362.

Wolfenzon, D. 1999. A theory of pyramidal ownership. Mimeo, University of Michigan Business School.

Zwiebel, J. 1995, Block investment and partial benefits of control. Review of Economic Studies 62: 161-185. 